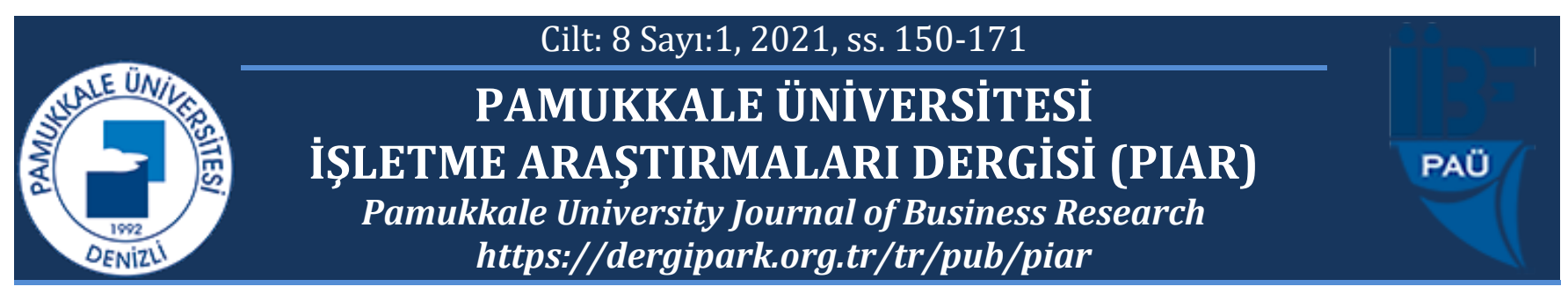

\title{
Petrol Fiyatları İle Borsa Endeksleri Arasındaki Karşılıklı İlişkinin VAR Yöntemi İle Analizi: Türkiye Ve Seçilmiş Ülkeler
}

\section{Analysis Of The Mutual Relationship Between Crude Oil Prices And Stock Market İndices By VAR Method: Turkey And Selected Countries}

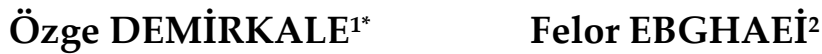

${ }^{1}$ İstanbul Aydın Üniversitesi, İşletme Bölümü, ozgedemirkale@aydin.edu.tr, https://orcid.org/0000- 0002-4227-3934 2 İstanbul Aydın Üniversitesi, Ekonomi ve Finans Bölümü, felorebghaei@aydin.edu.tr, https://orcid.org/0000-0002-98612675

* Yazışılan Yazar/Corresponding author

Makale Geliş/Received: 5 Mart 2021

Makale Kabul/Accepted: 28 Mayıs 2021

\section{Öz}

Bu çalışmanın amacı seçili gelişmiş ve gelişmekte olan ülkelerde emtia piyasasında bir yatırım aracı olarak işlem gören petrol fiyatlarının borsa endeksleri ile ilişkisini ve etkileşimini ortaya çıkarmaktır. Çalışmada 01/200806/2020 yılları arasinda aylık veriler kullanilarak petrol fiyatları ile hisse senedi piyasaları arasındaki karşılıkl ilişki zaman serisi yöntemlerinden VAR yöntemi kullanılarak analiz edilmiştir. Çalışmada analize dahil edilen her bir ülkenin öncelikle ayn seviyede dură̆anlı̆̆ sağlanan değişkenleri VAR modeline dayalı Granger nedensellik testi kullanılarak tahmin edilmiştir. Etki-tepki fonksiyonu ile ham petrol fiyatlarnda meydana gelecek bir birimlik şok karşısında değişkenlerin 10 dönem boyunca verdikleri tepkiler incelenmiştir. Ayrıca değişkenler arasındaki ilişkiler varyans ayrıştırma fonksiyonu ile değerlendirilmiştir. Çalışmadan elde edilen nedensellik analizi sonuçlarına göre DAXSanayi, BEL20, CAC Sanayi, BIST100, Bovespa, Hindistan PetrolEGaz, FTSE Endonezya ve sanayi endekslerinden petrol değişkenine doğru tek yönlü bir nedensellik ilişkisi saptanmıştır. BSE Sensex 30 endeksi ile ham petrol değ işkeni arasında ise çift yönlü bir nedensellik ilişkisi olduğu tespit edilmiştir. Etkitepki analizi sonuçlarma göre petrol fiyatlarında meydana gelebilecek bir şok karşısında endekslerin tepkisinin zayıf formda pozitif velveya negatif olduğu saptanmıştır. Ancak endekslerden birinde meydana gelebilecek bir şok karşısında petrol değisşkenin anlamlı tepkiler verdiği tespit edilmiştir.

Anahtar kelimeler: Borsa Endeksleri, Petrol Fiyatlar, Granger Nedensellik Testi, VAR Yöntemi.

JEL kodlart: C01, E00, G00

\begin{abstract}
The aim of this study is to identify the relationship and interaction of oil prices traded as an investment tool in the commodity market in selected developed and developing countries with stock market indices. In the study, the mutual relationship between oil prices and stock markets was analyzed using the VAR method using monthly data between 01/2008-06/2020. The variables of each country included in the analysis in the study were estimated using the VAR system with the Granger causality test. The effect-response function examined the reactions of variables over 10 periods in the face of a unit shock that will occur in crude oil prices. According to the results of the causality analysis obtained from the study, a one-way causality relationship was determined from DAX industry, BEL20, CAC industry, BIST100, Bovespa, Indian OilEGas, FTSE Indonesia and industry indices towards the oil variable. It was found that there is a bidirectional causal relationship between the BSE Sensex 30 index and the crude oil variable. According to the results of the effect-response analysis, it was determined that the reaction of the indices in the face of a shock that may occur in oil prices was positive and/or negative in poor form. But in the face of a shock that may occur in one of the indices, the oil variable has been found to give meaningful responses.
\end{abstract}

Keywords: Stock Market Indices, Oil Prices, Granger Causality Test, VAR method.

JEL codes: C01, E00, G00 


\section{GİRIŞ}

Petrol günümüz ekonomilerinde önemli bir enerji kaynağı ve ülkelerin imalat sürecinde kullanılan bir girdi unsuru olması nedeniyle petrol fiyatlarında meydana gelen değişimler yakından takip edilmektedir. Literatürde yapılan çalışmalar incelendiğinde petrol ithal eden ülkelerle birlikte petrol ihraç eden ülkelerde de fiyatlarda meydana gelen ani dalgalanmalar sermaye piyasaları ve makroekonomik değişkenleri olumlu ve olumsuz yönde etkileyebilmektedir. Özellikle 1973 yılında petrol fiyatlarında yaşanan ilk önemli şokun ardından petrol fiyatlarındaki değişim ve makroekonomik faktörler arasındaki ilişkiyi inceleyen araştırmalar başlamıştır. Hamilton'un 1983 yılında petrol fiyatlarındaki artışın ekonominin resesyona girmesinin kolaylaştırdığını iddia ettiği çalışması bu konuda yapılan ilk çalışmalardan birini oluşturmaktadır.

Finansal sistem içerisinde yatırımcıların emtia piyasalarında yaşanan gelişmelerle birlikte petrolü bir yatırım aracı olarak değerlendirmeleri petrolün, ülkelerin sermaye piyasaları başta olmak üzere finansal göstergelerine etkisini de artırmaktadır. Bu bağlamda petrol fiyatlarında meydana gelebilecek olan değişimlerin hisse senedi piyasalarına olan etkisinin piyasa öncüleri ve yatırımcılar açısından araştırılması gerekmektedir.

Hisse senedi getirilerini etkileyen faktörlerin doğru bir şekilde tespit edilmesi ülkenin sermaye piyasasının gelişimi, etkinliği ve verimliliğinin artırması açısından bununla birlikte ülkenin ekonomik büyümesine olumlu katkı yapması açısından oldukça önemlidir. Bu bağlamda hisse senedi getirilerine etki eden faktörleri ülkeye özgü, sektöre özgü faktörler açısından sinıflandırılmaktadır. Enerji, altın fiyatlarında meydana gelen değişimler, enflasyon ve faiz oranı, döviz kuru, ekonomik büyüme, para arzı gibi makroekonomik faktörlerin hisse senedi piyasalarını etkileyen makroekonomik faktörlerin başında yer almaktadır (Güngör ve Yerdelen, 2015: 149).

Literatürde petrol fiyatlarındaki değişimleri borsa endeksi, faiz ve enflasyon oranlarını içeren değişkenlerle nedensellik ilişkisi tespit edilen önemli çalışmalar bulunmaktadır. Bu çalışmalarda petrol fiyatlarındaki artışın özellikle ithalatçı ülkelerin ekonomilerine olumsuz bir etki ederken petrol fiyatlarında meydana gelen bir düşüşün ekonomiyi olumlu yönde etkilediğine dair ampirik kanıtlar tespit edilmiştir. Gelişmiş ülkelerde petrol fiyatlarının hisse senedi piyasalarını pozitif etki oluşturduğu tespit edilirken gelişmekte olan ülkelerde bu tepkinin negatif olduğu tespit edilmiştir (Regnier, 2007: 408).

$\mathrm{Bu}$ çalışmanın amacı seçili gelişmiş ve gelişmekte olan ülkelerde bir yatırım aracı olarak işlem gören petrol fiyatlarının borsa endeksleri ile ilişkisini ve etkileşimini ortaya çıkarmaktır. Ocak 2008-Haziran 2020 yılları arasında aylık verilerin kullanıldığı çalışmada petrol fiyatları ile hisse senedi piyasaları arasındaki karşılıklı ilişki VAR yöntemi kullanılarak analiz edilmiştir. Literatürde petrol fiyatları ile hisse senedi piyasaları arasındaki ilişkiyi inceleyen çalışmalara yer verildikten sonra çalışmanın metodolojisi ve veri seti tanıtılmıştır. Son bölümde ise çalışmadan elde edilen ampirik bulgulara yer verilmiştir.

\section{LITTERATÜR}

Literatürde petrol fiyatları ile borsa endeksleri arasındaki ilişkiyi inceleyen birçok çalışma mevcuttur. Söz konusu çalışmalar gelişmiş ve gelişmekte olan ülkeleri kapsamakla birlikte büyük bir bölümü gelişmiş ülke gruplarını araştırmaktadır. Bu bölümde petrol fiyatlarının 
borsa endeksleri üzerindeki etkisini çeşitli yöntemler kullanarak araştıran ulusal ve uluslararası çalışmalardan bazılarına kronolojik olarak yer verilmiştir

Petrol fiyatlarının hisse senedi üzerindeki etkilerini inceleyen ilk çalışmalardan biri Jones ve Kaul (1996) tarafından gerçekleştirilmiştir. Çalışmada 1970-1991 yılları arasındaki çeyreklik veriler kullanılarak petrol fiyatlarındaki değişimin ABD, Kanada, Japonya ve İngiltere hisse senedi piyasalarındaki etkisi analiz edilmiştir. Sonuçlara göre hisse senetlerinin petrol fiyatlarında meydana gelen değişimlerden etkilendiği tespit edilmiştir.

Sadorsky (1999), 1947-1996 dönemi için ABD'de petrol fiyatlarındaki değişimin S\&P 500 hisse senedi getirileri arasındaki ilişkiyi VAR yöntemi ile analiz etmiştir. Sonuç, petrol fiyatlarında meydana gelen değişimin pay senedi piyasası üzerinde etkili olduğu saptanmıştır.

Hammoudeh ve Eleisa (2004), 1994-2001 yılları arasında, Bahreyn, Kuveyt, Umman, Suudi Arabistan ve Birleşik Arap Emirlikleri için hisse senedi ve petrol fiyatları arasındaki ilişkiyi VAR yöntemini kullanarak incelemişlerdir. Analiz sonucuna göre Suudi Arabistan için hisse senedi ve petrol fiyatları arasında çift bir ilişki olduğu tespit edilmiştir.

Maghyereh (2004), 1998-2004 yılları arasında Türkiye'nin de aralarında bulunduğu 22 gelişmekte olan ülkede petrol fiyatları ile hisse senetleri arasındaki ilişkiyi VAR yöntemini kullanarak incelemiştir. Sonuç, hisse senedi getirilerinin petrol fiyatlarında meydana gelen şoklardan etkilenmediği tespit edilmiştir.

El-Sharif vd. (2005), 1989-2001 dönemi İngiltere için petrol ve gaz sektöründe faaliyet gösteren işletmelerin pay senetleri ile petrol fiyatları arasındaki ilişkiyi araştırmışlardır. Sonuç, petrol fiyatlarının hisse senedi getirileri üzerindeki etkisinin pozitif ve anlamlı olduğu tespit edilmiştir.

Basher ve Sadorsky (2006), 1992-2005 dönemi aylık verilerini kullanarak yirmi bir gelişen araştırdıkları çalışmalarında petrol fiyatlarında meydana gelen bir artışın hisse senedi getirilerini pozitif yönde etkilediğini tespit etmişlerdir.

Park ve Ratti (2008), 1986-2005 yılları arasında 14 gelişmiş ülke için petrol fiyatları ile borsa endeksleri arasındaki ilişkiyi VAR yöntemini kullanarak incelemişlerdir. Sonuç; petrol fiyatlarında meydana gelen değişimlerin borsa endeksleri üzerinde etkisi olduğu sonucuna ulaşmışlardır.

Narayan ve Narayan (2009), Vietnam için 2000-2008 dönemi günlük verilerini kullanarak petrol fiyatları, döviz kurları ve hisse senedi piyasaları arasındaki ilişkiyi Johansen EşBütünleşme yöntemi ile incelemişlerdir. Analizden elde edilen sonuçlara göre değişkenlerin uzun dönem ilişkiye sahip olduğu tespit edilmiştir.

Güler vd. (2010), 2000-2009 yılları arasında Türkiye için enerji sektörüne ilişkin hisse senedi fiyatları ile petrol fiyatları arasındaki ilişkiyi nedensellik testi ile araştırdıkları çalışmalarında petrol değişkeninden hisse senedi değişkenine doğru bir ilişki olduğu saptanmıştır.

Ono (2011), 1991-2009 yılları arasında BRIC ülkeleri için petrol fiyatları ile hisse senedi getirileri arasındaki ilişkiyi VAR yöntemi ile analiz etmiştir. Sonuç, petrol fiyatlarında meydana gelen değişimleri Çin, Hindistan ve Rusya piyasalarında işlem gören hisse senedi getirilerini olumlu yönde etkilediği saptanmıştır. 
Chittedi (2012), 2000-2011 yılları arasında Hindistan için hisse senedi ve petrol fiyatları arasındaki ilişkiyi ARDL modeli ile incelemiştir. Çalışmadan elde edilen sonuçlara göre hisse senedi getirilerinde meydana gelen değişimlerin petrol fiyatlarını etkilediği sonucuna ulaşmıştır.

Aktaş ve Akdağ (2013), 2008-2012 yılları arasındaki aylık verileri kullanarak BIST100 endeksi ile ham petrol ve altın fiyatları, faiz ve enflasyon oranı, döviz kuru, işsizlik oranı ve birçok makroekonomik faktör arasındaki ilişkiyi çoklu regresyon ve Granger yöntemlerini kullanarak analiz etmişlerdir. BIST100 ile altın ve petrol fiyatları arasında anlamlı bir ilişki tespit edilmemiştir.

Güler ve Nalın (2013), 1997-2012 dönemi için Türkiye'de BIST100 başta olmak üzeri petrol fiyatları ile ilişkili olan endeksleri nedensellik yöntemiyle analiz etmişlerdir. Çalışmada değişkenler arasında herhangi bir ilişki tespit edilmemiştir.

Kök ve Uyğur (2013), 2005-2012 yılları arasında aylık verileri kullanarak BIST100 endeksi, brent petrol, dolar kuru ve altın fiyatlarına (ons) ait değişkenleri kullanarak analiz etmişlerdir. VAR yönteminin kullanıldığı çalışmada İMKB100 endeksi ile altın fiyatları ve dolar kuru ile altın fiyatları arasında anlamlı bir etki-tepki olmadığı sonucuna ulaşmışlardır. Bununla birlikte araştırmacılar borsa endeksinin dolar fiyatlarındaki şoklar negatif, brent fiyatlarındaki şoklara ise pozitif tepki verdiğini tespit etmişlerdir.

Özmerdivanlı (2014), 2003-2014 yılları arasında BIST100 endeksi ile petrol fiatları arasındaki ilişkiyi Granger nedensellik yöntemini kullanarak analiz etmişlerdir. Sonuç, BIST100 endeksinden petrol fiyatlarına doğru tek yönlü bir ilişki saptanmıştır.

Pradhan vd. (2015), 1961-2012 yılları arasında G-20 ülkelerinin borsa derinliği, petrol fiyatları, faiz ve enflasyon oranı, döviz kuru arasındaki ilişkiyi panel vektör otoregresif yöntemi yardımıyla incelemişlerdir. Çalışmadan elde edilen sonuçlara göre uzun vadede borsa derinliği, petrol fiyatları ve analize dahil edilen diğer değişkenler arasında ilişki olduğu bulgusuna ulaşılmıştır.

Basher ve Sadorsky (2016), Ocak 2000 - Temmuz 2014 yılları arasındaki günlük verileri kullanarak Türkiye' nin de içinde olduğu 23 gelişmekte olan ülkenin hisse senedi, petrol, altın, tahvil ve VIX fiyatları arasındaki ilişkiyi incelemişlerdir. Sonuç, hisse senedi fiyatları ile petrol fiyatları arasında pozitif kaldıraç etkisi olduğu bulgusuna ulaşılmıştır.

Öget ve Şahin (2017), 1997-2014 yılları arasında günlük verileri kullanarak Türkiye için BIST100 endeksi ile ham petrol ve altın fiyatları arasındaki ilişkiyi Johansen Eşbütünleşme Testi ve VECM modelini kullanarak incelemişlerdir. Çalışmadan elde edilen sonuç, analize dahil edilen değişkenler arasında uzun dönemli bir ilişki olduğu yönündedir.

Syzdykova (2018), 2006-2016 yılları arasında aylık verileri kullanarak BRIC ülkelerinin borsa endeksleri ile petrol fiyatları, döviz kuru ve faiz oranı arasındaki ilişkiyi panel regresyon yöntemini kullanarak incelemiştir. Analizden elde edilen sonuçlar petrol fiyatlarındaki değişimlerin hisse senedi getirileri üzerinde anlamlı ve negatif bir etkiye sahip olduğu yönündedir.

Kakacak vd. (2020), 2000-2020 yılları arasında brent petrol ve BIST100 arasındaki ilişkiyi VAR yöntemini kullanarak araştırmışlardır. Çalışmadan elde edilen bulgulara nedensellik analizi 
sonuçlarına göre brent petrolün BIST100 endeksinin nedeni olduğu tespit edilirken etki-tepki analizi sonucunda değişkenler arasında anlamlı bir ilişki tespit edilmemiştir.

Kiracı (2020), 2000-2018 yılları arasında günlük verileri kullanarak BIST Ulaştırmak endeksi, dolar kuru ve petrol fiyatları arasındaki nedensellik ilişkisini Granger nedensellik analizi ve Hatemi-J asimetrik nedensellik yöntemini kullanarak araştırmıştır. Sonuç, petrol fiyatları serisinde pozitif ya da negatif yönlü bir şokun yaşanması durumunda BİST Ulaştırma endeksi serisinde de benzer yönlü şokların yaşanacağ 1 tespit edilmiştir.

Gürlevik ve Gazel (2020), 2010-2019 yılları arasında üçer aylık BİST Elektrik Endeksi elektrik fiyatları gaz fiyatları ve brent petrol fiyatları değişkenlerini kullanarak incelemişlerdir. NARDL sınır testi sonuçlarına göre uzun dönemde BIST Elektrik Endeksi ile gaz fiyatları arasında negatif yönlü ve anlamlı bir ilişki bulunmuştur. BIST Elektrik Endeksi ile elektrik fiyatları ve brent petrol fiyatları arasında ise uzun dönemde anlamlı bir ilişkiye rastlanamamıştır. Hata düzeltme modeli sonuçlarına göre ise uzun dönemli sonuçların aksine neredeyse tüm bağımsız değişkenler ile BİST Elektrik Endeksi arasında ilişki bulunmuştur.

Tüzemen (2021), 2009-2016 yılları arasında günlük verileri kullanarak petrol fiyatlarındaki değişimin BİST 100 endeksi içerisinde yer alan hizmet sektörü ve alt sektörleri üzerine asimetrik etkisini VAR-EGARCH modeli ile araştırmıştır. Elde edilen sonuçlara göre petrol fiyatlarında yaşanan negatif şokların etkisi özellikle turizm sektöründe önemli bir boyutta iken hizmet sektöründe bu etkinin diğer sektörlere göre daha zayıf formda olduğu tespit edilmiştir.

\section{YÖNTEM VE VERI SETİ}

Değişkenler arasında ekonometrik olarak anlamlı sonuçlar elde edebilmek için analize dahil edilen değişkenlerin durağan olup olmadığının araştırılması gerekmektedir. Serilerin durağanlığının araştırılması için literatürde en çok tercih edilen yöntemler Geliştirilmiş Dickey Fuller (ADF) ve Phillips Peron testleridir. ADF testi eşitliği aşağıdaki eşitlikte verilmiştir:

$\Delta Y_{t}=\beta_{1}+\beta_{2} t+\delta Y_{t-1}+\sum_{i}^{p} a_{t} \Delta Y_{t-1}+\varepsilon_{t}$

ADF testi ile değişkenlerin sabit ve sabit ve trendli durağanlığı analiz edilirken $H_{0}: \delta=$ 0 ve $H_{1}: \delta<0$ hipotezleri kurulur. Eğer $\mathrm{H} 0$ hipotezi kabul edilirse bu durum seride birim kök olduğunu göstermektedir. Analizden anlamlı sonuçlar elde edebilmek için durağanlık sağlanıncaya kadar serinin farkının veya doğal logaritmasını alınması gerekmektedir.

ADF testini uygularken dikkat edilmesi gereken en önemli konulardan biri de uygun gecikme uzunluğunun belirlenmesidir. Gecikme uzunluğu belirlenirken AIC (Akaike) ve SIC (Schwarz) bilgi kriterlerinden yararlanılabilir (Fuller, 1996). Bu çalışmada analize dahil edilen tüm serilerin durağanlık analizi ADF birim kök testi yardımıyla araştırılmıştır. Uygun gecikme uzunluğu belirlenirken tüm seriler için Schwarz bilgi kriterinden faydalanılmıştır

Çalışmada analize dahil edilen ülkeler için değişkenler arasında kısa dönemli ilişkiyi ortaya koyabilmek için Granger (1969) tarafından geliştirilen Granger Nedensellik Testi kullanılmıştır. Granger nedensellik testi durağanlı̆̆1 sağlanan değişkenlerle VAR sistemi kullanılarak tahmin edilmiştir. Sims (1980), tarafından geliştirilen VAR modeli analize dahil 
edilen değişkenlerin birbirileriyle olan ilişkilerini incelemekte ve değişkenlerden birinde meydana gelebilecek olan bir standart hatalık şokun diğer değişkenler üzerindeki etkisin araştırmak için kullanılmaktadır.

VAR yöntemi tüm değişkenleri içsel olarak kabul etmektedir. Bu yöntemin uygulanabilmesi için serilerin durağan hale getirilmesi gerekmektedir. Durağanlığı sağlanan serilerle VAR modeli oluştururken uygun gecikme uzunluğu AIC, SIC, HQ (Hannan-Quinn) gibi bilgi kriterleri yardımıla belirlenmektedir. Uygun gecikme uzunluğu tespit edilen modelde otokorelasyon ve değişen varyans sorununun olmadığının tespit edilmesi gerekmektedir. Bu çalışmada analize dahil edilen ülkeler için kurulan VAR modelinde otokorelasyon probleminin olup olmadığının sınanması için Lagrange Çarpanı (Lagrange Multiplier -LM) testi kullanılmıştır.

Çalışmada analize dahil edilen ülkelerin borsa endeksleri ve ham petrol fiyatlarının Ocak 2008 - Haziran 2020 dönemi aylık verileri kullanılmıştır. Çalışma kapsamında yer alan ülkeler ve pay senedi piyasası göstergesi olarak kullanılan borsa endeks adları Tablo 1'de yer almaktadır. Çalışmada kullanılan veri seti Sermaye Piyasası Kurulu, Investing.com - Stock Market Quotes \& Financial News sitelerinden derlenmiştir.

$\mathrm{Bu}$ çalışmanın literatürde yapılan diğer çalışmalardan farkı gelişmiş ve gelişmekte olan ülkelerde emtia piyasasında bir yatırım aracı olarak işlem gören petrol fiyatlarının borsa endeksleri ile ilişkisini ve etkileşimini ortaya çıkarmaktır. Bu bağlamda petrol fiyatları ile BIST100, BIST Sanayi, BIST Kimya, Petrol\&Plastik, Dolar/TL, faiz oranı değişkenlerinin karşılıklı duyarlılıklarını VAR yöntemi kullanarak araştırdığımız çalışmanın genişleterek sadece ülkelerin borsa endeksleri ile petrol fiyatları arasındaki karşılıklı ilişkiye odaklanılmıştır. (Demirkale ve Ebghaei, 2020). Analize dahil edilen ülkeler Petrol İhraç Eden Ülkeler Örgütü (OPEC) dişında kalan bazı ülkeleri oluşturmaktadır. Bu bağlamda petrol fiyatlarında meydana gelen değişimlerin etkisi gelişmiş ve gelişmekte olan ülkeler üzerinden elde edilen bulgular açısından incelenmiş ve elde edilen sonuçlar ülkeler arasında karşılaştırılabilmiştir.

Tablo 1. Değişkenlere ait bilgiler

\begin{tabular}{|l|l|}
\hline \multicolumn{1}{|c|}{ Ülke } & \multicolumn{1}{c|}{ Borsa Endeksleri } \\
\hline Türkiye & BIST100, BISTKIMPETROL\&PLASTIK, BISTSANAYI \\
\hline Almanya & DAXKIMYA, DAXSANAYI \\
\hline Belçika & BEL20, BELSANAYI \\
\hline Fransa & CACPetrol\&Gaz, CACSANAYI \\
\hline Brezilya & Bovespa \\
\hline Endonezya & FTSE Indonesia, Sanayi \\
\hline Hindistan & BSE Sensex 30, Petrol\&Gaz \\
\hline
\end{tabular}

\section{AMPİRIKK BULGULAR VE DEĞERLENDİRMELER}

Analize dahil edilen değişkenlerin durağan olup olmadığının araştırılması için bir önceki bölümde belirtildiği üzere ADF birim kök testi yapılmıştır. Tablo 2'den görüldüğü üzere değişkenlerin seviye değerlerinde birim kök vardır. Doğal logaritmaları alınan değişkenlere ait seriler durağan çıkmıştır. 
Tablo 2. Değişkenlerin Seviye ve Log Değerlerinde ADF Birim Kök Testi Sonuçları

\begin{tabular}{|c|c|c|c|c|c|c|c|c|}
\hline \multicolumn{5}{|c|}{ Seviye } & \multicolumn{4}{|c|}{ Log } \\
\hline Türkiye & \multicolumn{2}{|c|}{ Sabit } & \multicolumn{2}{|c|}{ Sabit ve trendli } & \multicolumn{2}{|c|}{ Sabit } & \multicolumn{2}{|c|}{ Sabit ve trendli } \\
\hline Değişkenler & $\begin{array}{c}\mathrm{t}- \\
\text { Statistic }\end{array}$ & Prob. & $\begin{array}{c}\mathrm{t}- \\
\text { Statistic }\end{array}$ & Prob. & $\begin{array}{c}\mathrm{t}- \\
\text { Statistic } \\
\end{array}$ & Prob. & $\begin{array}{c}\mathrm{t}- \\
\text { Statistic }\end{array}$ & Prob. \\
\hline BIST100 & -1.092675 & $\begin{array}{c}0.718 \\
0 \\
\end{array}$ & $\begin{array}{c}- \\
1.580395 \\
\end{array}$ & $\begin{array}{c}0.796 \\
4 \\
\end{array}$ & $\begin{array}{c}- \\
12.35488 \\
\end{array}$ & $\begin{array}{c}0.000 \\
0 \\
\end{array}$ & $\begin{array}{c}- \\
12.48525 \\
\end{array}$ & $\begin{array}{c}0.000 \\
0 \\
\end{array}$ \\
\hline $\begin{array}{l}\text { BISTKIMPETROL\&PLAST } \\
\text { IK }\end{array}$ & -0.248023 & $\begin{array}{c}0.928 \\
3\end{array}$ & $\begin{array}{c}- \\
3.158870\end{array}$ & $\begin{array}{c}0.096 \\
8\end{array}$ & $\begin{array}{c}- \\
12.22534\end{array}$ & $\begin{array}{c}0.000 \\
0\end{array}$ & $\begin{array}{c}- \\
12.18048\end{array}$ & $\begin{array}{c}0.000 \\
0\end{array}$ \\
\hline BISTSANAYI & 0.197402 & $\begin{array}{c}0.971 \\
7\end{array}$ & $\begin{array}{c}- \\
3.378945\end{array}$ & $\begin{array}{c}0.058 \\
1\end{array}$ & $\begin{array}{c}- \\
11.59365\end{array}$ & $\begin{array}{c}0.000 \\
0\end{array}$ & $\begin{array}{c}- \\
11.54800\end{array}$ & $\begin{array}{c}0.000 \\
0\end{array}$ \\
\hline Ham Petrol & -1.779190 & $\begin{array}{c}0.389 \\
7 \\
\end{array}$ & $\begin{array}{c}- \\
2.338511 \\
\end{array}$ & $\begin{array}{c}0.410 \\
4 \\
\end{array}$ & $\begin{array}{c}- \\
8.764428 \\
\end{array}$ & $\begin{array}{c}0.000 \\
0 \\
\end{array}$ & $\begin{array}{c}- \\
8.742262 \\
\end{array}$ & $\begin{array}{c}0.000 \\
0 \\
\end{array}$ \\
\hline \multicolumn{5}{|c|}{ Seviye } & \multicolumn{4}{|c|}{ Log } \\
\hline Almanya & \multicolumn{2}{|c|}{ Sabit } & \multicolumn{2}{|c|}{ Sabit ve trendli } & \multicolumn{2}{|c|}{ Sabit } & \multicolumn{2}{|c|}{ Sabit ve trendli } \\
\hline Değişkenler & t-Statistic & Prob. & $\begin{array}{c}\mathrm{t}- \\
\text { Statistic } \\
\end{array}$ & Prob. & $\begin{array}{c}\mathrm{t}- \\
\text { Statistic } \\
\end{array}$ & Prob. & $\begin{array}{c}\mathrm{t}- \\
\text { Statistic } \\
\end{array}$ & Prob. \\
\hline DAXKIMYA & -0.842910 & $\begin{array}{l}0.803 \\
6 \\
\end{array}$ & $\begin{array}{l}- \\
2.618651 \\
\end{array}$ & $\begin{array}{l}0.272 \\
8 \\
\end{array}$ & $\begin{array}{l}- \\
10.42626\end{array}$ & $\begin{array}{l}0.000 \\
0 \\
\end{array}$ & $\begin{array}{l}- \\
10.39807 \\
\end{array}$ & $\begin{array}{l}0.000 \\
0 \\
\end{array}$ \\
\hline DAXSANAYI & -0.919392 & $\begin{array}{l}0.779 \\
9 \\
\end{array}$ & $\begin{array}{l}- \\
3.131900 \\
\end{array}$ & $\begin{array}{l}0.067 \\
4 \\
\end{array}$ & $\begin{array}{l}- \\
10.90295\end{array}$ & $\begin{array}{l}0.000 \\
0 \\
\end{array}$ & $\begin{array}{l}- \\
10.86579 \\
\end{array}$ & $\begin{array}{l}0.000 \\
0\end{array}$ \\
\hline Ham Petrol & -1.779190 & $\begin{array}{c}0.389 \\
7\end{array}$ & $\begin{array}{c}- \\
2.338511\end{array}$ & $\begin{array}{c}0.410 \\
4\end{array}$ & $\begin{array}{c}- \\
8.764428\end{array}$ & $\begin{array}{c}0.000 \\
0\end{array}$ & $\begin{array}{c}- \\
8.742262\end{array}$ & $\begin{array}{c}0.000 \\
0\end{array}$ \\
\hline \multicolumn{5}{|c|}{ Seviye } & \multicolumn{4}{|c|}{ Log } \\
\hline Belçika & \multicolumn{2}{|c|}{ Sabit } & \multicolumn{2}{|c|}{ Sabit ve trendli } & \multicolumn{2}{|c|}{ Sabit } & \multicolumn{2}{|c|}{ Sabit ve trendli } \\
\hline Değişkenler & t-Statistic & Prob. & $\begin{array}{c}\mathrm{t}- \\
\text { Statistic }\end{array}$ & Prob. & $\begin{array}{c}\mathrm{t}- \\
\text { Statistic }\end{array}$ & Prob. & $\begin{array}{c}\mathrm{t}- \\
\text { Statistic }\end{array}$ & Prob. \\
\hline BEL20 & -1.918683 & $\begin{array}{l}0.323 \\
0 \\
\end{array}$ & $\begin{array}{l}- \\
3.171955\end{array}$ & $\begin{array}{l}0.075 \\
5 \\
\end{array}$ & $\begin{array}{l}- \\
10.16598 \\
\end{array}$ & $\begin{array}{l}0.000 \\
0 \\
\end{array}$ & $\begin{array}{l}- \\
10.15945\end{array}$ & $\begin{array}{l}0.000 \\
0\end{array}$ \\
\hline BELSANAYI & -1.957347 & $\begin{array}{l}0.305 \\
5 \\
\end{array}$ & $\begin{array}{l}- \\
2.511761\end{array}$ & $\begin{array}{l}0.322 \\
1 \\
\end{array}$ & $\begin{array}{l}- \\
9.502647\end{array}$ & $\begin{array}{l}0.000 \\
0 \\
\end{array}$ & $\begin{array}{l}- \\
9.471146 \\
\end{array}$ & $\begin{array}{l}0.000 \\
0\end{array}$ \\
\hline Ham Petrol & -1.779190 & $\begin{array}{c}0.389 \\
7 \\
\end{array}$ & $\begin{array}{c}- \\
2.338511 \\
\end{array}$ & $\begin{array}{c}0.410 \\
4 \\
\end{array}$ & $\begin{array}{c}- \\
8.764428 \\
\end{array}$ & $\begin{array}{c}0.000 \\
0 \\
\end{array}$ & $\begin{array}{c}- \\
8.742262 \\
\end{array}$ & $\begin{array}{c}0.000 \\
0 \\
\end{array}$ \\
\hline \multicolumn{5}{|c|}{ Seviye } & \multicolumn{4}{|c|}{ Log } \\
\hline Fransa & \multicolumn{2}{|c|}{ Sabit } & \multicolumn{2}{|c|}{ Sabit ve trendli } & \multicolumn{2}{|c|}{ Sabit } & \multicolumn{2}{|c|}{ Sabit ve trendli } \\
\hline Değişkenler & t-Statistic & Prob. & $\begin{array}{c}\mathrm{t}- \\
\text { Statistic }\end{array}$ & Prob. & $\begin{array}{c}\mathrm{t}- \\
\text { Statistic }\end{array}$ & Prob. & $\begin{array}{c}\mathrm{t}- \\
\text { Statistic }\end{array}$ & Prob. \\
\hline CACPetrol\&Gaz & -3.308951 & $\begin{array}{l}0.016 \\
2 \\
\end{array}$ & $\begin{array}{l}- \\
3.297399\end{array}$ & $\begin{array}{l}0.070 \\
6 \\
\end{array}$ & $\begin{array}{l}- \\
12.10891\end{array}$ & $\begin{array}{l}0.000 \\
0 \\
\end{array}$ & $\begin{array}{l}- \\
12.08818 \\
\end{array}$ & $\begin{array}{l}0.000 \\
0 \\
\end{array}$ \\
\hline CACSANAYI & -0.938823 & $\begin{array}{l}0.773 \\
5 \\
\end{array}$ & $\begin{array}{l}- \\
3.511476 \\
\end{array}$ & $\begin{array}{l}0.046 \\
7 \\
\end{array}$ & $\begin{array}{l}- \\
10.99628 \\
\end{array}$ & $\begin{array}{l}0.000 \\
4 \\
\end{array}$ & $\begin{array}{l}- \\
10.96538 \\
\end{array}$ & $\begin{array}{l}0.000 \\
0 \\
\end{array}$ \\
\hline Ham Petrol & -1.779190 & $\begin{array}{c}0.389 \\
7 \\
\end{array}$ & $\begin{array}{c}- \\
2.338511 \\
\end{array}$ & $\begin{array}{c}0.410 \\
4 \\
\end{array}$ & $\begin{array}{c}- \\
8.764428 \\
\end{array}$ & $\begin{array}{c}0.000 \\
0 \\
\end{array}$ & $\begin{array}{c}- \\
8.742262 \\
\end{array}$ & $\begin{array}{c}0.000 \\
0 \\
\end{array}$ \\
\hline \multicolumn{5}{|c|}{ Seviye } & \multicolumn{4}{|c|}{$\log$} \\
\hline Brezilya & \multicolumn{2}{|c|}{ Sabit } & \multicolumn{2}{|c|}{ Sabit ve trendli } & \multicolumn{2}{|c|}{ Sabit } & Sabit ve & endli \\
\hline Değişkenler & t-Statistic & Prob. & $\begin{array}{c}\mathrm{t}- \\
\text { Statistic }\end{array}$ & Prob. & $\begin{array}{c}\mathrm{t}- \\
\text { Statistic }\end{array}$ & Prob. & $\begin{array}{c}\mathrm{t}- \\
\text { Statistic }\end{array}$ & Prob. \\
\hline Bovespa & -1.086429 & $\begin{array}{l}0.720 \\
5\end{array}$ & $\begin{array}{l}- \\
2.116137\end{array}$ & $\begin{array}{l}0.532 \\
3\end{array}$ & $\begin{array}{l}- \\
10.56648\end{array}$ & $\begin{array}{l}0.000 \\
0\end{array}$ & $\begin{array}{l}- \\
10.56895\end{array}$ & $\begin{array}{l}0.000 \\
0\end{array}$ \\
\hline Ham Petrol & -1.779190 & $\begin{array}{c}0.389 \\
7 \\
\end{array}$ & $\begin{array}{c}- \\
2.338511 \\
\end{array}$ & $\begin{array}{c}0.410 \\
4 \\
\end{array}$ & $\begin{array}{c}- \\
8.764428 \\
\end{array}$ & $\begin{array}{c}0.000 \\
0 \\
\end{array}$ & $\begin{array}{c}- \\
8.742262 \\
\end{array}$ & $\begin{array}{c}0.000 \\
0 \\
\end{array}$ \\
\hline & Seviy & & & & & Log & & \\
\hline Endonezya & Sabi & & Sabit ve & rendli & $\mathrm{Sab}$ & & Sabit ve & rendli \\
\hline
\end{tabular}




\begin{tabular}{|c|c|c|c|c|c|c|c|c|}
\hline Değişkenler & t-Statistic & Prob. & $\begin{array}{c}\mathrm{t}- \\
\text { Statistic }\end{array}$ & Prob. & $\begin{array}{c}\mathrm{t}- \\
\text { Statistic }\end{array}$ & Prob. & $\begin{array}{c}\mathrm{t}- \\
\text { Statistic }\end{array}$ & Prob. \\
\hline FTSE Indonesia & -1.297589 & $\begin{array}{l}0.630 \\
0 \\
\end{array}$ & $\begin{array}{l} \\
2.258992\end{array}$ & $\begin{array}{l}0.453 \\
3 \\
\end{array}$ & $\begin{array}{l}- \\
10.05156\end{array}$ & $\begin{array}{l}0.000 \\
0 \\
\end{array}$ & $\begin{array}{l}- \\
10.04191\end{array}$ & $\begin{array}{l}0.000 \\
0\end{array}$ \\
\hline Sanayi & -1.097791 & $\begin{array}{l}0.716 \\
0 \\
\end{array}$ & $\begin{array}{l}- \\
2.645977\end{array}$ & $\begin{array}{l}0.260 \\
8 \\
\end{array}$ & $\begin{array}{l}- \\
11.38620\end{array}$ & $\begin{array}{l}0.000 \\
0 \\
\end{array}$ & $\begin{array}{l}- \\
11.35939\end{array}$ & $\begin{array}{l}0.000 \\
0\end{array}$ \\
\hline Ham Petrol & -1.779190 & $\begin{array}{c}0.389 \\
7 \\
\end{array}$ & $\begin{array}{c}- \\
2.338511 \\
\end{array}$ & $\begin{array}{c}0.410 \\
4 \\
\end{array}$ & $\begin{array}{c}- \\
8.764428 \\
\end{array}$ & $\begin{array}{c}0.000 \\
0 \\
\end{array}$ & $\begin{array}{c}- \\
8.742262\end{array}$ & $\begin{array}{c}0.000 \\
0\end{array}$ \\
\hline \multicolumn{5}{|c|}{ Seviye } & \multicolumn{4}{|c|}{ Log } \\
\hline Hindistan & \multicolumn{2}{|c|}{ Sabit } & \multicolumn{2}{|c|}{ Sabit ve trendli } & \multicolumn{2}{|c|}{ Sabit } & \multicolumn{2}{|c|}{ Sabit ve trendli } \\
\hline Değişkenler & t-Statistic & Prob. & $\begin{array}{c}\mathbf{t}- \\
\text { Statistic }\end{array}$ & Prob. & $\begin{array}{c}\mathbf{t}- \\
\text { Statistic }\end{array}$ & Prob. & $\begin{array}{c}\mathrm{t}- \\
\text { Statistic }\end{array}$ & Prob. \\
\hline BSE Sensex 30 & -0.451446 & $\begin{array}{l}0.896 \\
0 \\
\end{array}$ & $\begin{array}{l}- \\
4.181635\end{array}$ & $\begin{array}{l}0.006 \\
0 \\
\end{array}$ & $\begin{array}{l}- \\
11.53406\end{array}$ & $\begin{array}{l}0.000 \\
0 \\
\end{array}$ & $\begin{array}{l}- \\
11.50266\end{array}$ & $\begin{array}{l}0.000 \\
0 \\
\end{array}$ \\
\hline Petrol\&Gaz & -1.969273 & $\begin{array}{l}0.300 \\
2 \\
\end{array}$ & $\begin{array}{l}- \\
3.679320\end{array}$ & $\begin{array}{l}0.056 \\
7 \\
\end{array}$ & $\begin{array}{l}- \\
12.55848\end{array}$ & $\begin{array}{l}0.000 \\
0 \\
\end{array}$ & $\begin{array}{l}- \\
12.51811\end{array}$ & $\begin{array}{l}0.000 \\
0 \\
\end{array}$ \\
\hline Ham Petrol & -1.779190 & $\begin{array}{c}0.389 \\
7\end{array}$ & $\begin{array}{c}- \\
2.338511\end{array}$ & $\begin{array}{c}0.410 \\
4\end{array}$ & $\begin{array}{c}- \\
8.764428\end{array}$ & $\begin{array}{c}0.000 \\
0\end{array}$ & $\begin{array}{c}- \\
8.742262\end{array}$ & $\begin{array}{c}0.000 \\
0\end{array}$ \\
\hline
\end{tabular}

Türkiye için kurulan VAR modelinde gecikme uzunluğu 4, AIC (Akaike information Criterion) testi yardımıyla belirlenmiştir.

Tablo 3. Gecikme Uzunluğunun Belirlenmesi

\begin{tabular}{|c|c|c|c|c|c|}
\hline Lag & LR & FPE & AIC & SC & HQ \\
\hline 0 & NA & $3.61 \mathrm{e}-08$ & -5.785848 & $-5.703353^{*}$ & $-5.752327^{*}$ \\
\hline 1 & 31.83794 & $3.58 \mathrm{e}-08$ & -5.792676 & -5.380202 & -5.625070 \\
\hline 2 & 45.16173 & $3.21 \mathrm{e}-08$ & -5.904985 & -5.162532 & -5.603294 \\
\hline 3 & 21.01091 & $3.41 \mathrm{e}-08$ & -5.843151 & -4.770719 & -5.407375 \\
\hline 4 & 61.88272 & $2.63 \mathrm{e}-08^{*}$ & $-6.108195^{*}$ & -4.705783 & -5.538334 \\
\hline 5 & 14.44962 & $2.93 \mathrm{e}-08$ & -6.003449 & -4.271058 & -5.299503 \\
\hline 6 & 26.39905 & $2.95 \mathrm{e}-08$ & -6.003068 & -3.940697 & -5.165037 \\
\hline 7 & 17.92308 & $3.17 \mathrm{e}-08$ & -5.936698 & -3.544349 & -4.964582 \\
\hline 8 & $26.74514^{*}$ & $3.15 \mathrm{e}-08$ & -5.955423 & -3.233094 & -4.849222 \\
\hline
\end{tabular}

LM olasılık değeri 0.2449 kurulan VAR modelinde otokorelasyon sorunun olmadığını göstermektedir.

Tablo 4. LM Otokorelasyon Test Sonucu

\begin{tabular}{|c|c|c|}
\hline Gecikmeler & LM-İstatistiği & Olasılık \\
\hline 1 & 22.88945 & 0.1167 \\
\hline 2 & 23.87635 & 0.0922 \\
\hline 3 & 17.82180 & 0.3344 \\
\hline 4 & $\mathbf{1 9 . 4 7 2 7 6}$ & $\mathbf{0 . 2 4 4 9}$ \\
\hline
\end{tabular}

Normallik için JB istatistiği 1.152403 (p-değeri: 0.5620) olarak hesaplanmış ve hata terimleri normal dağılıma sahiptir sıfır hipotezi \%5 önem düzeyinde kabul edilmiştir. Son olarak değişen varyansın varlığını test etmek için ki-kare istatistiği 284.9283 (p-değeri: 0.9213) olarak elde edilmiş ve hata terimleri arasında değişen varyans yoktur sıfır hipotezi \%5 önem düzeyinde kabul edilmiştir. \%5 anlamlılık seviyesinde değişen varyans probleminin de olmadığ 1 görülmektedir 
Tablo 5. White Değişen Varyans ve Normallik Testi

\begin{tabular}{|l|l|l|l|l|}
\hline Chi-sq & df & Prob. & Jarque-Bera & Prob. \\
\hline 284.9283 & 320 & 0.9213 & 1.152403 & 0.5620 \\
\hline
\end{tabular}

AR Karakteristik polinomunun ters köklerinin birim çember içerisindeki konumları modelin durağan olduğunu göstermektedir.

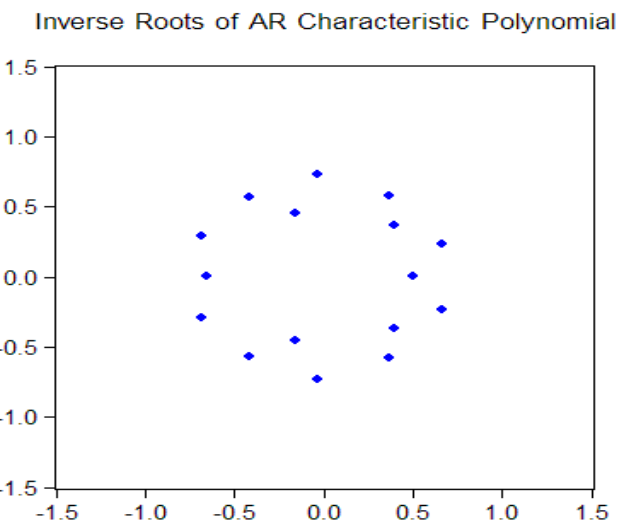

Şekil 1: AR Birim Kökleri

Granger nedensellik test sonuçlarına göre modelde yer alan değişkenler arasında BIST100' den ham petrol değişkenine doğru bir nedensellik ilişkisi tespit edilmiştir. Analizde ayrıca BIST KimPetrol\&Plastık ile BIST100 ve BIST Sanayi ile BIST100 değişkenleri arasında çift yönlü bir nedensellik ilişkisi saptanmıştır (Tablo 6).

Tablo 6. Nedensellik Testi

\begin{tabular}{|c|c|c|}
\hline Parametreler & Df & Olasılık \\
\hline BIST100 $\longrightarrow$ Ham Petrol & 4 & 0.0000 \\
\hline BISTKİMPETROL $\longrightarrow$ BIST100 & 4 & 0.0178 \\
\hline BIST SANAYI $\longrightarrow$ BIST100 & 4 & 0.0181 \\
\hline$\longrightarrow$ BISTKIMMPETROL & 4 & 0.0016 \\
\hline BIST100 $\quad \longrightarrow \quad$ BIST SANAYI & 4 & 0.0002 \\
\hline
\end{tabular}

Etki-tepki fonksiyonu ile değişkenlerin birinde meydana gelecek bir birimlik şok karşısında diğer değişkenlerin tepkisi incelenmiştir. Buna göre petrol fiyatlarında meydana gelebilecek bir birimlik şok karşısında BIS100 etkisinin zayıf formda negatif BISTKIMPETROL\&PLASTIK ve BIST Sanayi endekslerinin ise zayıf formda pozitif yönde olduğu tespit edilmiştir. Bununla birlikte BIST100 endeksinde meydana gelebilecek bir standart sapmalık şok karşısında petrol değişkenin tepkisi üçüncü döneme kadar negatif iken bu dönemden itibaren pozitif değerler aldığı görülmektedir. BISTKIMPETROL\&PLASTIK birinde meydana gelebilecek bir şok karşısında petrol değişkeni pozitif tepki verirken sanayi endeksine petrol değişkeninin tepkisi üçüncü döneme kadar pozitif iken dördüncü dönemde negatif değerler almakta altıncı dönem itibariyle denge değerine doğru yaklaşmaktadır (Şekil 2). 


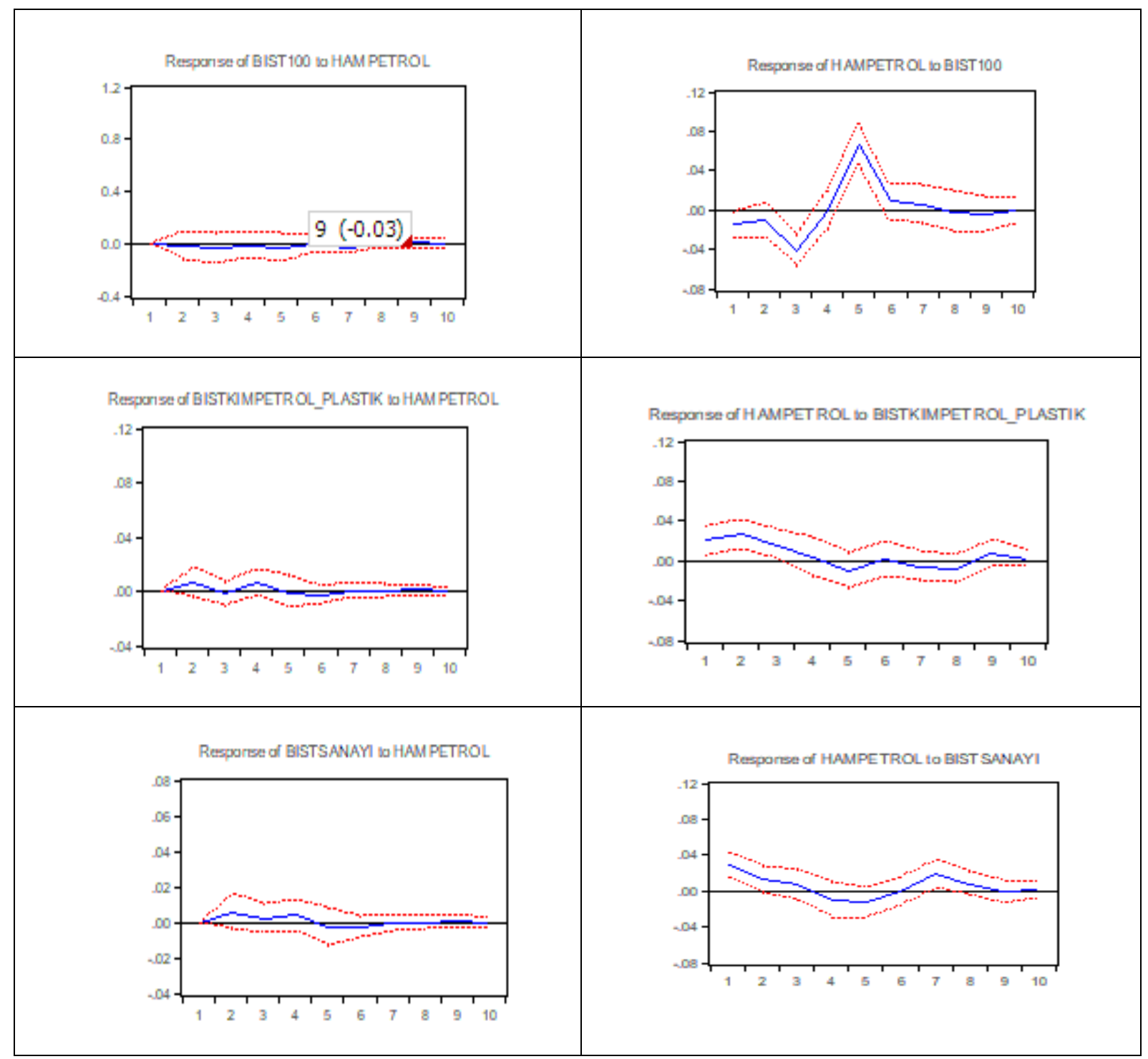

\section{Şekil 2: Etki-Tepki Analizi Sonuçları}

Petrol değişkenindeki değişimleri incelediğimizde birinci dönemde varyansının \%82 değişkenin kendisi tarafından açılanırken \%10'u BIST Sanayi değişkeni tarafından açıklanmaktadır. Dönemler ilerledikçe değişkenin varyansındaki değişimleri en çok açıklayan değişkenin ilerledikçe BIST100 endeksi olduğu görülmektedir (Tablo 7).

Tablo 7. Petrol Değişkeninin Varyans Ayrışım Sonuçları

\begin{tabular}{|c|c|c|c|c|}
\hline \multicolumn{5}{|c|}{ Ham Petrol Varyans Ayrışım Tablosu } \\
\hline Dönem & BIST100 & BISTKim.P.P. & BISTSanayi & Ham Petrol \\
\hline 1 & 2.776604 & 4.968340 & 10.16575 & 82.08930 \\
\hline 2 & 3.694559 & 12.05334 & 10.70826 & 73.54383 \\
\hline 6 & 40.83166 & 9.004222 & 8.108547 & 42.05558 \\
\hline 9 & 39.54405 & 9.610714 & 10.37484 & 40.47040 \\
\hline 10 & 39.53907 & 9.616466 & 10.37941 & 40.46506 \\
\hline
\end{tabular}

Almanya için kurulan VAR modelinde gecikme uzunluğu 2 AIC bilgi kriteri yardımıyla tespit edilmiştir. VAR modelin hata terimleri için normallik, otokorelasyon ve değişen varyans 
sınamaları yapılmıştır. Gecikme uzunluğu 2 olan modelde LM istatistiği 13.52097 (p-değeri: 0.1404) olarak belirlenmiş ve hata terimleri arasında otokorelasyon yoktur sıfır hipotezi \%5 önem düzeyinde kabul edilmiştir. Normallik için JB istatistiği 1.605797 (p-değeri: 0.4480) olarak hesaplanmış ve hata terimleri normal dağılıma sahiptir sıfır hipotezi \%5 önem düzeyinde kabul edilmiştir. Son olarak değişen varyansın varlığını test etmek için ki-kare istatistiği 22.66577 (p-değeri: 0.0307) olarak elde edilmiş ve hata terimleri arasında değişen varyans yoktur sıfır hipotezi \%1 önem düzeyinde kabul edilmiştir. \%1 anlamlılık seviyesinde değişen varyans probleminin de olmadığı görülmektedir. Ayrıca değişkenlerin köklerini gösteren noktalar birim çemberin içinde yer almaktadır.

Zaman serisi çalışmalarında otokorelasyon sorunu, yatay kesit çalışmalarında ise değişen varyans sorunu görülebilmektedir. Özellikle finansal verilerde değişen varyans sorunu ön plandadır. Bu bağlamda çalışmamızın zaman serisi olması nedeni ile değişen varyans test sonucu için \%1 anlam düzeyi yeterli bulunmuştur (Kaygısız, 2018: 129).

Granger nedensellik test sonuçlarına göre DAX_SANAYI endeksinden DAX_KIMYA endeksine ve ham petrol değişkenine doğru tek yönlü bir nedensellik ilişkisi saptanmıştır (Tablo 8).

Tablo 8. Nedensellik Test Sonuçları

\begin{tabular}{|c|c|c|}
\hline Parametreler & Df & Olasıllk \\
\hline DAX_SANAYI $\longrightarrow$ DAX_KIMYA & 2 & 0.0393 \\
\hline DAX_SANAYI $\longrightarrow$ HAM_PETROL & 2 & 0.0762 \\
\hline
\end{tabular}

Petrol fiyatlarında meydana gelebilecek bir standart sapmalık şok karşısında DAX Kimya ve DAX Sanayi endekslerinin etkisinin tepkisi zayıf formda pozitiftir. DAX Kimya endeksinde meydana gelebilecek bir birimlik şok petrol değişkeni üçüncü döneme kadar pozitif tepki verirken dördüncü dönemde negatif değerler almakta ve bu dönemden itibaren denge değerine doğru yaklaşmaktadır. Sanayi endeksinde meydana gelebilecek şok karşısında ise petrol değişkeni ikinci döneme kadar pozitif değerler almakta üçüncü dönemde negatif bir eğilim göstermekle birlikte bu dönemde itibaren denge değerinde olduğu görülmektedir (Şekil 3). 


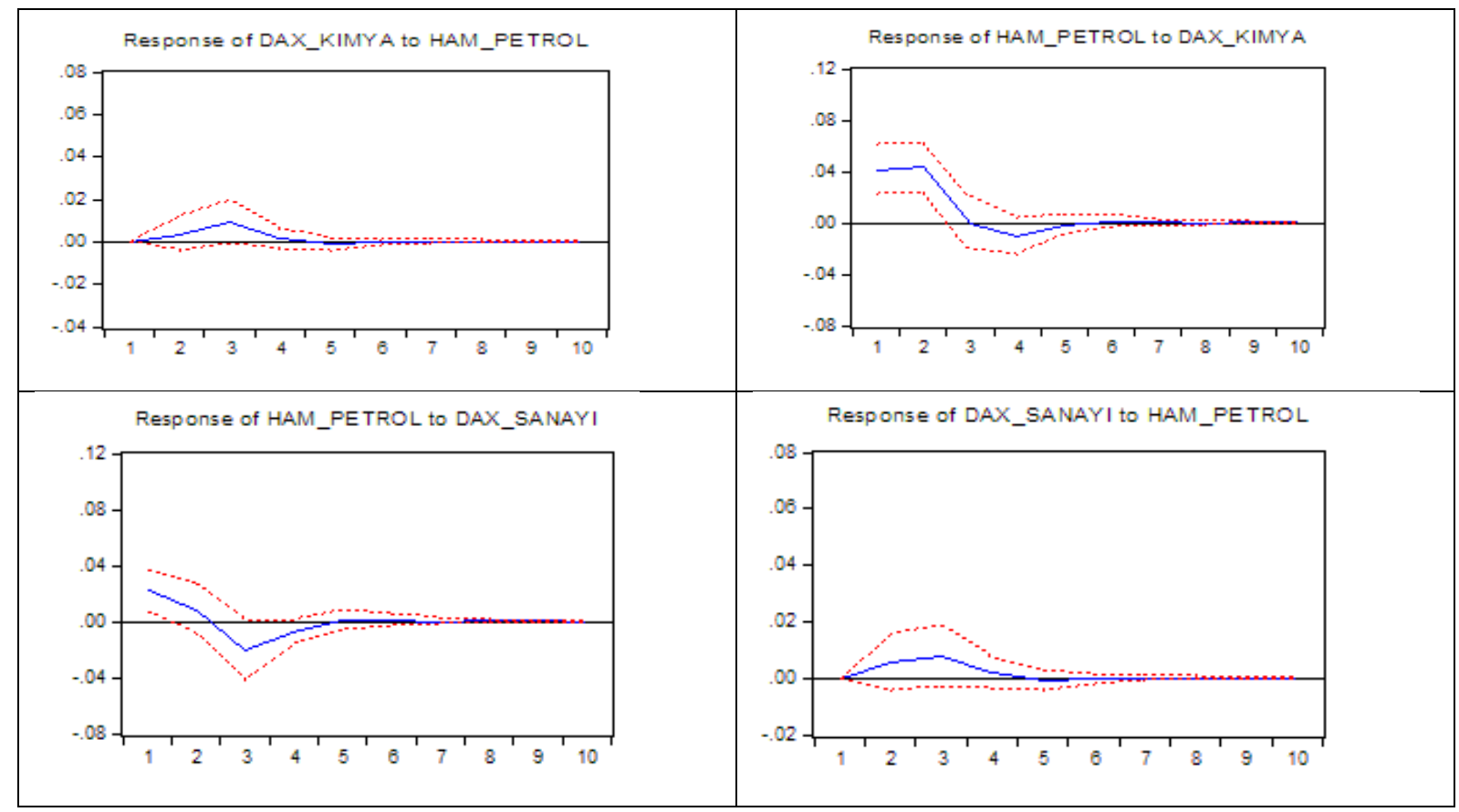

Şekil 3: Etki-Tepki Analizi Sonuçları

Ham petrol değişkeni; birinci dönemde değişkenin varyansının \%83'ü değişkenin kendisi tarafından açıklanmaktadır. Son dönem itibariyle ham petrol değişkeninin varyansının \%23'ü DAX Kimya, \%7'si DAX Sanayi ve \%70 değişkenin kendisi tarafından açılanmaktadır (Tablo 9).

Tablo 9. Petrol Değişkeninin Varyans Ayrışım Sonuçları

\begin{tabular}{|c|c|c|c|}
\hline \multicolumn{4}{|c|}{ Ham Petrol Varyans Ayrişım Tablosu } \\
\hline Dönem & DAX Kimya & DAX Sanayi & Ham Petrol \\
\hline 1 & 13.12068 & 3.690935 & 83.18838 \\
\hline 2 & 23.65996 & 3.612186 & 72.72785 \\
\hline 3 & 22.94335 & 6.453104 & 70.60354 \\
\hline 4 & 23.41038 & 6.764106 & 69.82551 \\
\hline 5 & 23.42132 & 6.767632 & 69.81105 \\
\hline 6 & 23.42256 & 6.774695 & 69.80274 \\
\hline 7 & 23.42237 & 6.774649 & 69.80298 \\
\hline 8 & 23.42236 & 6.774603 & 69.80304 \\
\hline 9 & 23.42238 & 6.774629 & 69.80299 \\
\hline 10 & 23.42239 & 6.774628 & 69.80298 \\
\hline
\end{tabular}

Belçika için kurulan VAR modelinde gecikme uzunluğu 1 AIC bilgi kriteri yardımıyla tespit edilmiştir. VAR modelin hata terimleri için otokorelasyon ve değişen varyans sınamaları yapılmıştır. Gecikme uzunluğu 1 olan modelde LM istatistiği 12.64321 (p-değeri: 0.1794) olarak belirlenmiş ve hata terimleri arasında otokorelasyon yoktur sıfır hipotezi \%5 önem düzeyinde kabul edilmiştir. Son olarak değişen varyansın varlığını test etmek için ki-kare istatistiği 47.97606 (p-değeri: 0.0875) olarak elde edilmiş ve hata terimleri arasında değişen varyans yoktur sıfır hipotezi \%5 önem düzeyinde kabul edilmiştir. Ayrıca değişkenlerin köklerini gösteren noktalar birim çemberin içinde yer almaktadır. 
Granger nedensellik test sonuçlarına göre BEL20 endeksinden ham petrol değişkenine doğru tek yönlü bir nedensellik ilişkisi saptanmıştır (Tablo 10).

Tablo 10. Nedensellik Testi

\begin{tabular}{|c|c|c|}
\hline Parametreler & Df & Olasıllk \\
\hline BEL_20 $\longrightarrow$ HAM_PETROL & 1 & 0.0059 \\
\hline
\end{tabular}

Petrol meydana gelebilecek bir birimlik şok karşısında BEL20 ve BEL Sanayi endekslerinin tepkisinin anlamlı olmadı görülmektedir. BEL 20 ve BEL sanayi endekslerinde meydana gelebilecek bir birimlik şok karşısında petrol değişkenin zayıf formda pozitif tepki verdiği tespit edilmiştir (Şekil 3).

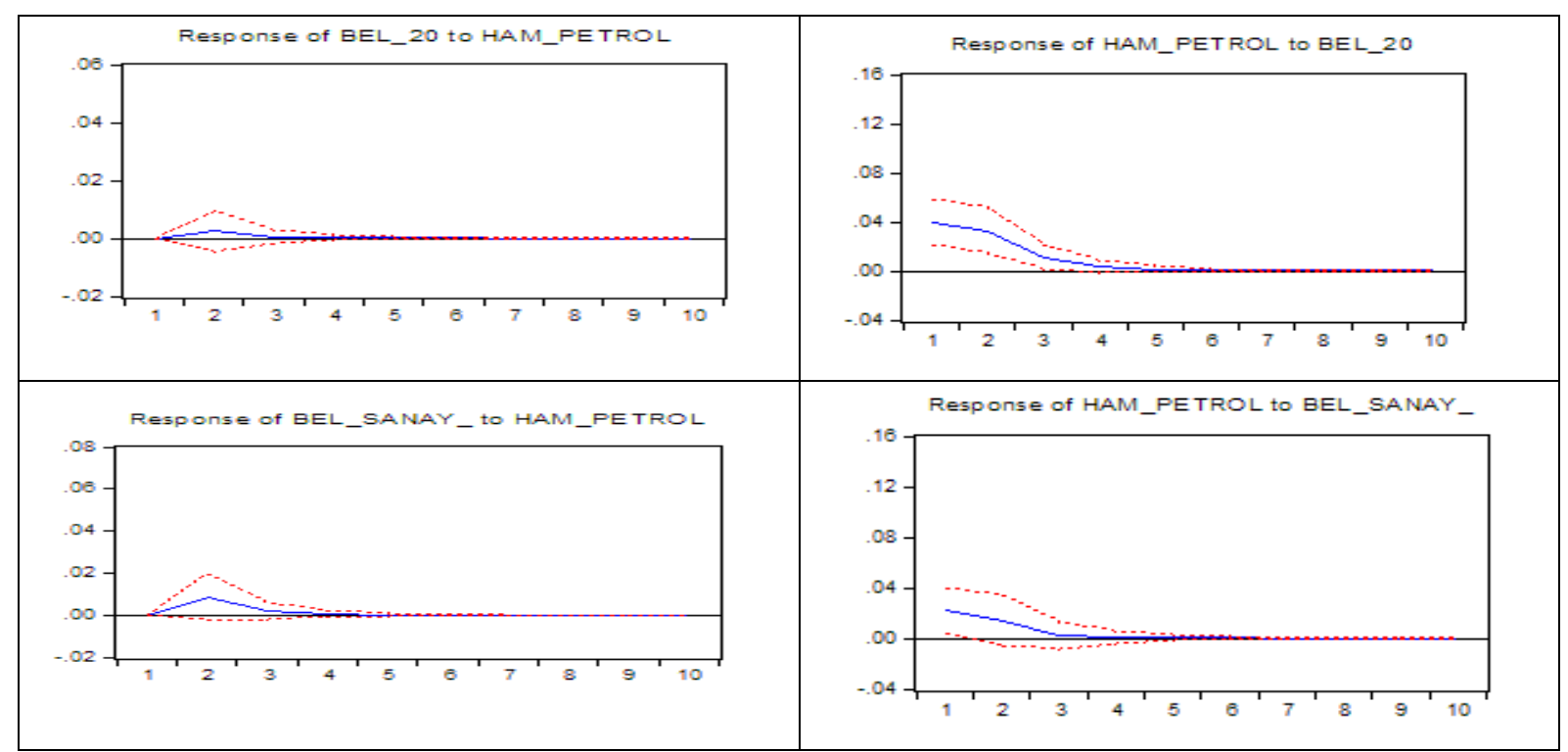

Şekil 4: Etki-Tepki Analizi Sonuçları

Tablo 11; BEL20, BEL Sanayi ve ham petrol fiyatlarındaki ilişkiyi ortaya çıkarmak adına yapılan varyans ayrışım tablosunu göstermektedir. Buna göre petrol değişkeni birinci dönemde varyansının \%85 oranında kendisi tarafından açıklandığı görülmektedir. Ham petrol değişkenini en çok açıklayan değişkenler sırasıyla \%18 ile BEL20 endeksi ve \%4 ile Bel Sanayi endeksidir.

Tablo 11. Petrol Değişkeninin Varyans Ayrışım Sonuçları

\begin{tabular}{|c|c|c|c|}
\hline \multicolumn{4}{|c|}{ Ham Petrol Varyans Ayrişım Tablosu } \\
\hline Dönem & BEL20 & BEL Sanayi & Ham Petrol \\
\hline 1 & 11.42249 & 3.461175 & 85.11633 \\
\hline 2 & 17.35535 & 4.351161 & 78.29349 \\
\hline 3 & 18.00950 & 4.335196 & 77.70915 \\
\hline 4 & 18.01350 & 4.332644 & 77.65785 \\
\hline 5 & 18.01377 & 4.332420 & 77.65408 \\
\hline 6 & 23.42256 & 4.332404 & 77.65383 \\
\hline 7 & 18.01378 & 4.332403 & 77.65381 \\
\hline 8 & 18.01378 & 4.332403 & 77.65381 \\
\hline 9 & 18.01378 & 4.332403 & 77.65381 \\
\hline 10 & 18.01378 & 4.332403 & 77.65381 \\
\hline
\end{tabular}


Fransa için kurulan VAR modelinde gecikme uzunluğu 1 AIC bilgi kriteri yardımıyla tespit edilmiştir. Gecikme uzunluğu 1 olan modelde LM istatistiği 12.96323 (p-değeri: 0.1643) olarak belirlenmiş ve hata terimleri arasında otokorelasyon yoktur sıfır hipotezi \%5 önem düzeyinde kabul edilmiştir. Normallik için JB istatistiği 2.461879 (p-değeri: 0.2920) olarak hesaplanmış ve hata terimleri normal dağılıma sahiptir sıfır hipotezi \%5 önem düzeyinde kabul edilmiştir. Son olarak değişen varyansın varlığını test etmek için ki-kare istatistiği 3.686679 (p-değeri: 0.7190) olarak elde edilmiş ve hata terimleri arasında değişen varyans yoktur sıfır hipotezi \%5 önem düzeyinde kabul edilmiştir. Ayrıca değişkenlerin köklerini gösteren noktalar birim çemberin içinde yer almaktadır.

Granger nedensellik test sonuçlarına göre CAC Sanayi endeksinden ham petrol değişkenine doğru tek yönlü bir nedensellik ilişkisi saptanmıştır (Tablo 12).

Tablo 12. Granger Nedensellik Testi

\begin{tabular}{|c|c|c|}
\hline Parametreler & Df & Olasılık \\
\hline CAC_SANAYI $\rightarrow$ HAM_PETROL & 1 & 0.0302 \\
\hline
\end{tabular}

Ham petrol fiyatlarında ki bir birimlik şok karşısında CAC Sanayi ve CAC Petrol\&Gaz endekslerinin tepkisinin anlamlı olmadığ 1 görülürken iki endekste meydana gelebilecek bir şok karşısında petrol değişkenin pozitif tepki verdiği saptanmıştır (Şekil 5).

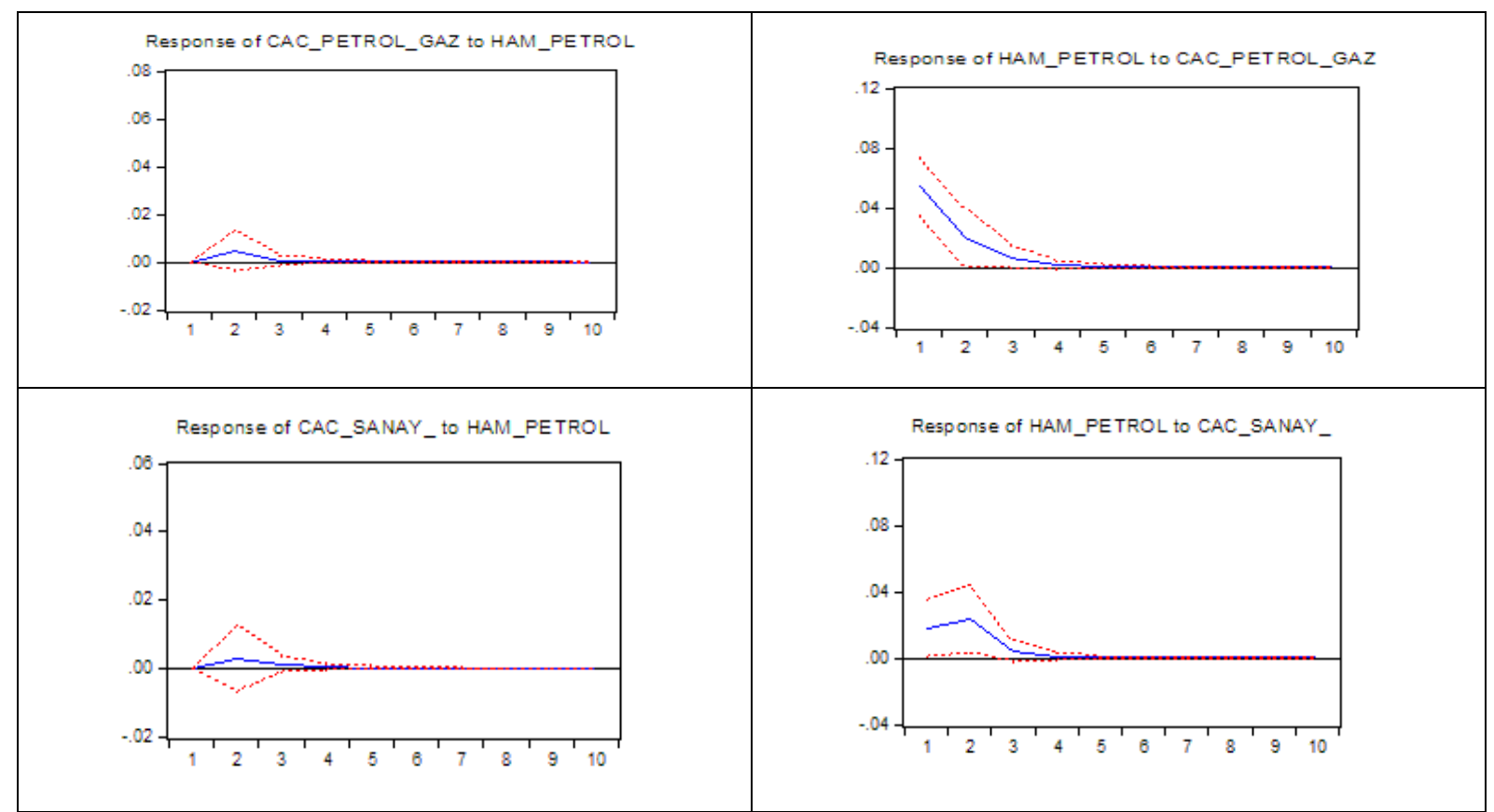

Şekil 5: Etki-Tepki Analizi Sonuçları

Ham petrol varyans ayrışım tablosuna göre birinci dönemde değişkenin varyansının \%83'ü değişkenin kendisi tarafından, \%16'sı CAC Sanayi endeksi tarafından açıklanmaktadır. Son dönem itibariyle ham petrol değişkeninin varyansının \%22'si CAC Sanayi endeksi, \%78'i değişkenin kendisi tarafından açıklanmaktadır (Tablo 13). 
Tablo 13. Petrol Değişkeninin Varyans Ayrışım Sonuçları

\begin{tabular}{|c|c|c|}
\hline \multicolumn{3}{|c|}{ Ham Petrol Varyans Ayrısım Tablosu } \\
\hline Dönem & CAC Sanayi & Ham Petrol \\
\hline 1 & 16.33091 & 83.66909 \\
\hline 2 & 21.32923 & 78.67077 \\
\hline 3 & 21.54930 & 78.45070 \\
\hline 4 & 21.56178 & 78.43822 \\
\hline 5 & 21.56248 & 78.43752 \\
\hline 6 & 21.56252 & 78.43748 \\
\hline 7 & 21.56252 & 78.43748 \\
\hline 8 & 21.56252 & 78.43748 \\
\hline 9 & 21.56252 & 78.43748 \\
\hline 10 & 21.56252 & 78.43748 \\
\hline
\end{tabular}

Brezilya için kurulan VAR modelinde gecikme uzunluğu 2 AIC bilgi kriteri yardımıyla tespit edilmiştir. Gecikme uzunluğu 2 olan modelde LM istatistiği 4.197287 (p-değeri: 0.3800) olarak belirlenmiş ve hata terimleri arasında otokorelasyon yoktur sıfır hipotezi \%5 önem düzeyinde kabul edilmiştir. Normallik için JB istatistiği 4.514489 (p-değeri: 0.1046) olarak hesaplanmış ve hata terimleri normal dağılıma sahiptir sıfır hipotezi \%5 önem düzeyinde kabul edilmiştir. Son olarak değişen varyansın varlığını test etmek için ki-kare istatistiği 15.7513 (p-değeri: 0.2029) olarak elde edilmiş ve hata terimleri arasında değişen varyans yoktur sıfır hipotezi \%1 önem düzeyinde kabul edilmiştir. \%5 anlamlılık seviyesinde değişen varyans probleminin de olmadığı görülmektedir. Ayrıca değişkenlerin köklerini gösteren noktalar birim çemberin içinde yer almaktadır.

Granger nedensellik analizi sonuçlarına göre Bovespa endeksinden petrol değişkenine doğru tek yönlü bir nedensellik ilişkisi saptanmıştır (Tablo 14).

Tablo 14. Granger Nedensellik Testi

\begin{tabular}{|c|c|c|}
\hline Parametreler & Df & Olasılık \\
\hline Bovespa $\rightarrow$ Ham Petrol & 2 & 0.0196 \\
\hline
\end{tabular}

Ham petrol fiyatlarında meydana gelecek bir birimlik şok karşısında Bovespa endeksinin tepkisinin dördüncü döneme kadar pozitif olduğu bu dönemden itibaren denge değerine doğru yaklaştığı görülmektedir. Bovespa endeksinde meydana gelebilecek bir birimlik şok karşısında ham petrol değişkeninin tepkisinin üçüncü döneme kadar pozitif olduğu dördüncü dönemde 0.007 lik negatif bir tepki vermekle birlikte bu dönemden itibaren sıfır denge değerine doğru yaklaştığı tespit edilmiştir (Şekil 6).

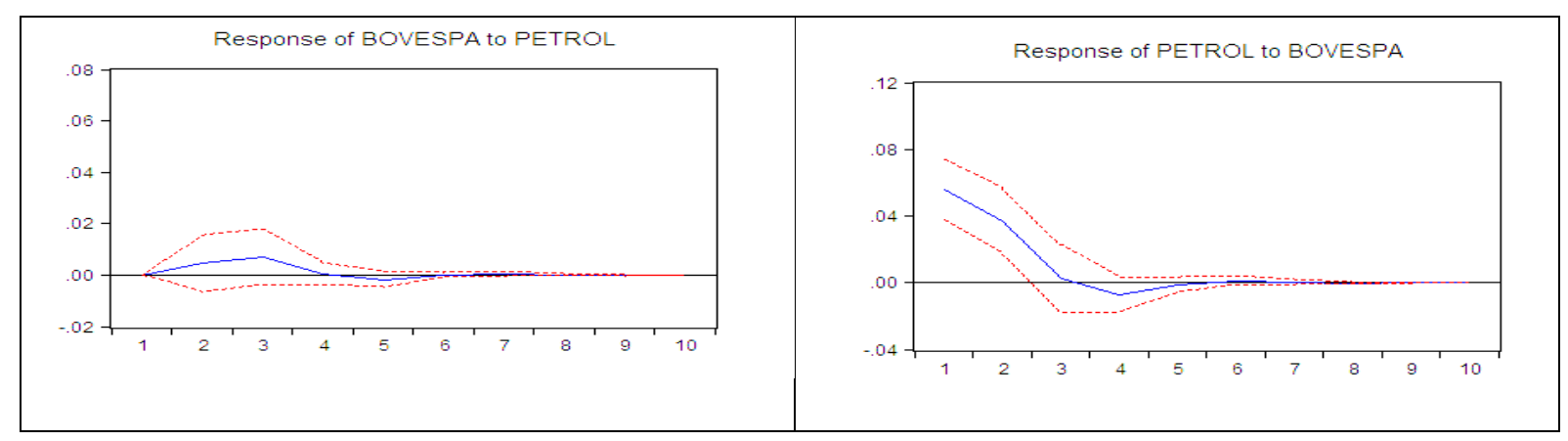

Şekil 6: Etki-Tepki Analizi Sonuçları 
Ham petrol değişkenin varyans ayrışım tablosuna göre birinci dönemde değişkenin varyansındaki değişimleri \%77'si değişkenin kendisi taradında \%22'si BOVESPA endeksi tarafından açıklanmaktadır. Dönemler itibariyle bu oranda büyük bir farklılık olmadığı görülmektedir (Tablo 15).

Tablo 15. Petrol Değişkeninin Varyans Ayrışım Tablosu

\begin{tabular}{|c|c|c|}
\hline \multicolumn{3}{|c|}{ Ham Petrol Varyans Ayrișim Tablosu } \\
\hline Dönem & BOVESPA & Ham Petrol \\
\hline 1 & 22.47987 & 77.52013 \\
\hline 2 & 29.23518 & 70.76482 \\
\hline 3 & 29.00734 & 70.99266 \\
\hline 4 & 29.25463 & 70.74537 \\
\hline 5 & 29.25728 & 70.74272 \\
\hline 6 & 29.26298 & 70.73702 \\
\hline 7 & 29.26280 & 70.73720 \\
\hline 8 & 29.26297 & 70.73703 \\
\hline 9 & 29.26295 & 70.73705 \\
\hline 10 & 29.26296 & 70.73704 \\
\hline
\end{tabular}

Endonezya için kurulan VAR modelinde gecikme uzunluğu 1 AIC, SC, HQ bilgi kriteri yardımıyla Gecikme uzunluğu 1 olan modelde LM istatistiği 6.127449 (p-değeri: 0.7271) olarak belirlenmiş ve hata terimleri arasında otokorelasyon yoktur sıfır hipotezi \%5 önem düzeyinde kabul edilmiştir. Değişen varyansın varlığını test etmek için p-değeri 0.0349 olarak elde edilmiş ve hata terimleri arasında değişen varyans yoktur sıfır hipotezi \%1 önem düzeyinde kabul edilmiştir. Ayrıca değişkenlerin köklerini gösteren noktalar birim çemberin içinde yer almaktadir.

Granger nedensellik test sonuçlarına göre sanayi endeksinden ham petrol değişkenine doğru tek yönlü bir ilişki tespit edilmiştir. Ayrıca FTSE Indonesia endeksinden ham petrol değişkenine doğru tek yönlü bir nedensellik ilişkisi olduğu görülmektedir (Tablo 16 ).

Tablo 16. Nedensellik Test Sonuçları

\begin{tabular}{|c|c|c|}
\hline Parametreler & Df & Olasılık \\
\hline SANAYI $\longrightarrow$ Ham Petrol & 1 & 0.0241 \\
\hline$\longrightarrow$ Ham Petrol & 1 & 0.0196 \\
\hline
\end{tabular}

Ham petrol fiyatlarında meydana gelebilecek bir birimlik şok karşısında FTSE Endonezya endeksinin tepkisinin anlamlı olmadığı Sanayi endeksinin tepkisinin ise zayıf formda negatif olduğu tespit edilmiştir. FTSE Endonezya ve Sanayi endekslerinde meydana gelebilecek bir standart sapmalık şok karşısında petrol değişkenin pozitif tepki verdiği görülmektedir (Şekil 7). 


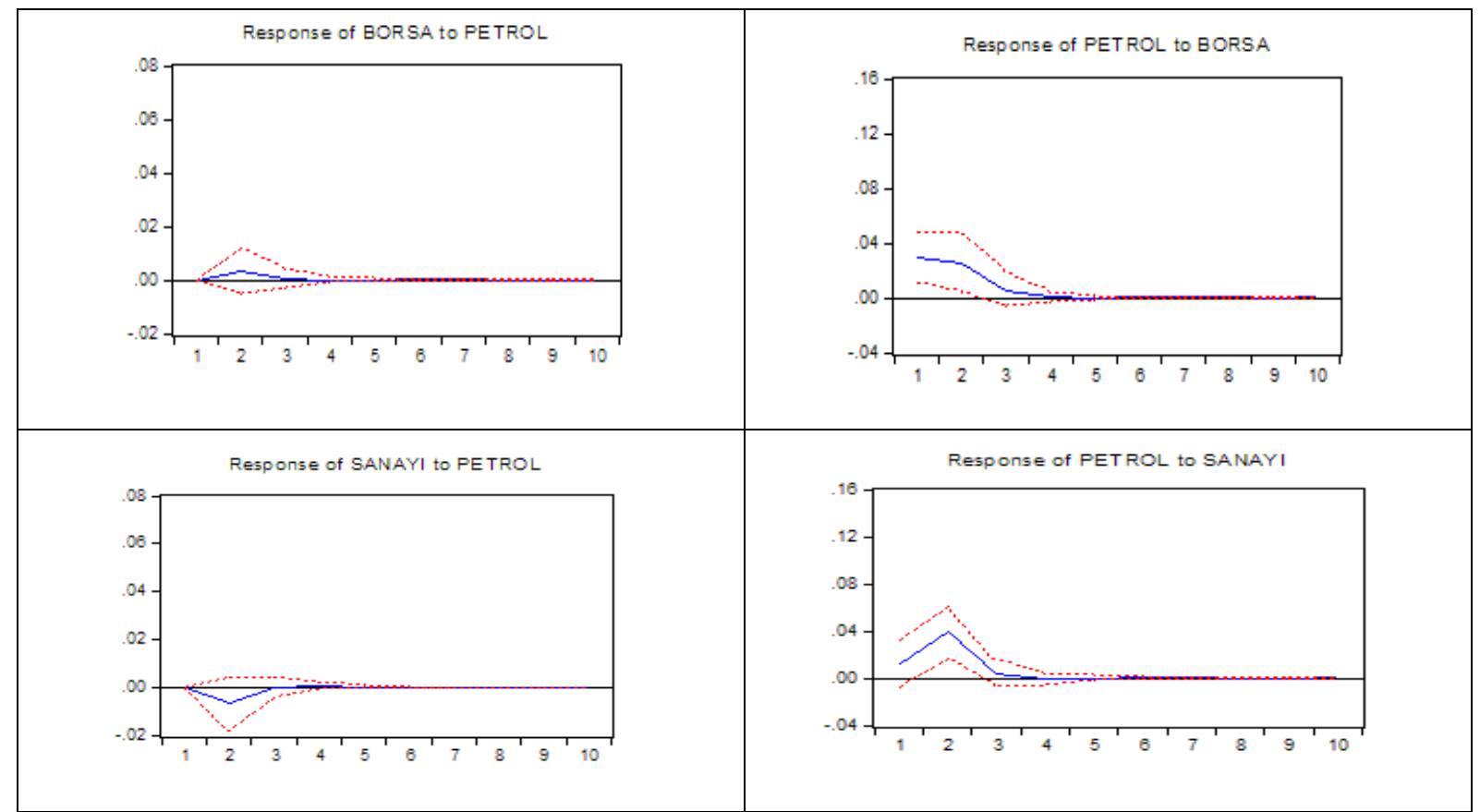

Şekil 7: Etki-Tepki Analizi Sonuçları

Ham petrol değişkeninin varyans ayrışım tablosunu incelediğimizde birinci dönemde değişkenin varyansındaki değişimlerin \%92'sinin değişkenin kendisi \%7'si FTSE Endonezya değişkeni tarafından açıklanmaktadır. Son dönemler itibariyle ham petrol değişkeninin varyansını \%11'ni Sanayi endeksi \%10'u FTSE Endonezya endeksi açıklamaktadır (Tablo 17).

Tablo 17. Petrol Değişkeninin Varyans Ayrışım Tablosu

\begin{tabular}{|l|l|l|l|}
\hline \multicolumn{4}{|l|}{ HAM PETROL Varyans Ayrısıım Tablosu } \\
\hline Dönem & FTSE Indonesia & Sanayi Endeksi. & Ham Petrol \\
\hline 1 & 6.698199 & 1.093210 & 92.20859 \\
\hline 2 & 9.546067 & 10.74951 & 79.70442 \\
\hline 3 & 9.691977 & 10.78115 & 79.52687 \\
\hline 4 & 9.690106 & 10.79179 & 79.51810 \\
\hline 5 & 9.690107 & 10.79202 & 79.51787 \\
\hline 6 & 9.690105 & 10.79204 & 79.51785 \\
\hline 7 & 9.690106 & 10.79204 & 79.51785 \\
\hline 8 & 9.690106 & 10.79204 & 79.51785 \\
\hline 9 & 9.690106 & 10.79204 & 79.51785 \\
\hline 10 & 9.690106 & 10.79204 & 79.51785 \\
\hline
\end{tabular}

Hindistan için kurulan VAR modelinde gecikme uzunluğu 2 AIC bilgi kriteri yardımıyla tespit edilmiştir. Gecikme uzunluğu 2 olan modelde LM istatistiği 11.01890 (p-değeri: 0.2744) otokorelasyon sorununun olmadı̆̆ını göstermektedir. Ayrıca değişkenlerin köklerini gösteren noktalar birim çemberin içinde yer almaktadır. Normallik için JB istatistiği 3.362428 (p-değeri: 0.1861) olarak hesaplanmış ve hata terimleri normal dağılıma sahiptir sıfır hipotezi \%5 önem düzeyinde kabul edilmiştir. Son olarak değişen varyansın varlığını test etmek için ki-kare istatistiği 19.12351 (p-değeri: 0.0856) olarak elde edilmiş ve hata terimleri arasında değişen varyans yoktur sıfır hipotezi \%5 önem düzeyinde kabul edilmiştir. Ayrıca değişkenlerin köklerini gösteren noktalar birim çemberin içinde yer almaktadır. 
Granger nedensellik test sonuçlarına göre BSE Sensex 30 endeksi ile ham petrol değişkeni arasında çift yönlü bir nedensellik ilişkisi saptanmıştır. Çalışmada ayrıca Petrol\&Gaz endeksinden ham petrol değişkenine doğru tek yönlü bir nedensellik ilişkisi olduğu tespit edilmiştir (Tablo 18).

Tablo 18. Granger Nedensellik Testi

\begin{tabular}{|c|l|l|}
\hline Parametreler & Df & Olasıllk \\
\hline Ham Petrol $\longrightarrow$ BSE Sensex 30 & 2 & 0.0269 \\
\hline BSE Sensex 30 $\longrightarrow$ Ham Petrol & 2 & 0.0284 \\
\hline BSE Petrol\&Gaz $\longrightarrow$ Ham Petrol & 2 & 0.0018 \\
\hline
\end{tabular}

Ham petrol değişkeninde meydana gelebilecek bir birimlik şok karşısında BSE Sensex endeksinin tepkisinin dördüncü döneme kadar zayıf formda pozitif olduğu bu dönemden itibaren denge değerine doğru yaklaştığ görülmektedir. BSE Sensex endeksinde meydana gelebilecek bir şok ise petrol değişkeni ikinci döneme kadar pozitif tepki verirken beşinci döneme kadar negatif değerler aldığı görülmektedir. Petrol fiyatında meydana gelebilecek bir şoka Hindistan'ın Petrol\&Gaz endeksi üçüncü döneme kadar zayıf formda pozitif tepki verirken altncı dönemden itibaren denge değerine yaklaştığı görülmektedir. Hindistan'ın Petrol\&Gaz endeksinde meydana gelebilecek bir şoka petrol değişkeni ikinci dönemden itibaren pozitif tepkiler vermekte ve beşinci dönem itibariyle denge değerine yaklaşmaktadır (Şekil 8).

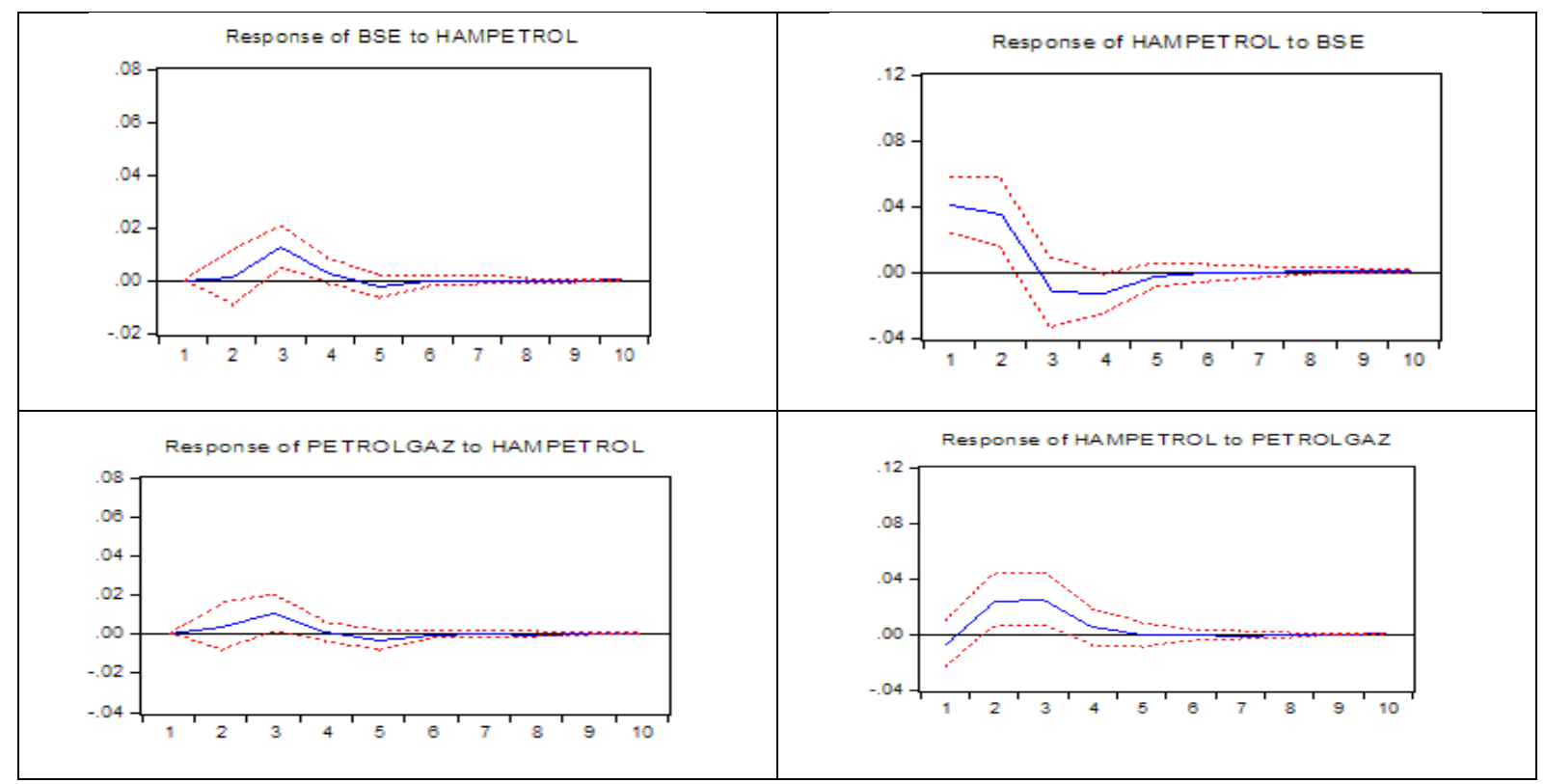

Şekil 8: Etki-Tepki Analizi Sonuçları

Ham petrol değişkeninin varyans ayrışım tablosuna göre birinci dönemde değişkenin varyansının \%87.2'si değişkenin kendisi, \%13'ü BSE Sensex 30 endeksi tarafından açıklanmaktadır. Son dönemler itibariyle ham petrol değişkeninin varyansının \%21'i BSE Sensex 30, \%8'i BSE Petrol\&Gaz endeksleri tarafından açıklandığı görülmektedir (Tablo 19). 
Tablo 19. Petrol Değişkeninin Varyans Ayrışım Tablosu

\begin{tabular}{|c|c|c|c|}
\hline \multicolumn{5}{|c|}{ HAM PETROL Varyans Ayrışım Tablosu } \\
\hline Dönem & BSE Sensex 30 & BSE Petrol\&Gaz & Ham Petrol \\
\hline 1 & 13.03813 & 0.000000 & 86.96187 \\
\hline 2 & 19.74455 & 4.272634 & 75.98281 \\
\hline 3 & 19.67640 & 8.017704 & 72.30590 \\
\hline 4 & 20.58086 & 8.062846 & 71.35630 \\
\hline 5 & 20.60254 & 8.065536 & 71.33193 \\
\hline 6 & 20.58428 & 8.068010 & 71.34771 \\
\hline 7 & 20.58163 & 8.083006 & 71.33536 \\
\hline 8 & 20.58311 & 8.087735 & 71.32915 \\
\hline 9 & 20.58512 & 8.087557 & 71.32733 \\
\hline 10 & 20.58513 & 8.087689 & 71.32718 \\
\hline
\end{tabular}

\section{SONUÇ VE ÖNERILER}

Bu çalışmada Ocak 2008 - Haziran 2020 dönemi için Türkiye ve seçilmiş ülkelerin seçili borsa endeksleri ile petrol fiyatları arasındaki ilişki VAR yöntemi kullanılarak analiz edilmiştir. Çalışmada analize dahil edilen her bir ülkenin öncelikle aynı seviyede durağanlığı sağlanan değişkenleri Granger nedensellik testi ile VAR sistemi kullanılarak tahmin edilmiştir. Etkitepki fonksiyonu ile değişkenlerde meydana gelecek bir birimlik şok karşısında değişkenlerin 10 dönem boyunca verdikleri tepki değerlendirilmiştir.

Literatürde petrol fiyatları ile borsa endeksleri arasındaki ilişkiyi inceleyen pek çok çalışma bulunmaktadır. Bilindiği üzere petrol fiyatlarında meydana gelen şoklar özellikle enerji kaynakları açısından dışa bağımlı ülkelerde sermaye piyasalarını ve makroekonomik göstergeleri etkileyebilmektedir. Çalışmalar incelendiğinde petrol fiyatlarındaki artışın sadece petrol ithal eden ülkelerde değil petrol ihraç eden ülkelerin de hisse senedi piyasalarını olumlu ya da olumsuz yönde etkileyebileceği yönünde bulgular tespit edilmiştir. Bu çalışmanın literatürde yapılan diğer çalışmalardan farkı gelişmiş ve gelişmekte olan ülkelerde emtia piyasasında bir yatırım aracı olarak işlem gören petrol fiyatlarının borsa endeksleri ile ilişkisini ve etkileşimini ortaya çıkarmaktır. Analize dahil edilen ülkeler Petrol İhraç Eden Ülkeler Örgütü (OPEC) dışında kalan bazı ülkeleri oluşturmaktadır. Bu bağlamda petrol fiyatlarında meydana gelen değişimlerin etkisi gelişmiş ve gelişmekte olan ülkeler üzerinden elde edilen bulgular açısından incelenmiş ve elde edilen sonuçlar ülkeler arasında karşılaştırılabilmiştir.

Almanya için yapılan Granger nedensellik test sonuçlarına göre DAXSanayi endeksinden ham petrol değişkenine doğru tek yönlü bir nedensellik ilişkisi saptanmıştır. Petrol fiyatlarında meydana gelebilecek bir standart sapmalık şok karşısında DAX Kimya ve DAX Sanayi endekslerinin etkisinin tepkisi zayıf formda pozitiftir. DAX Kimya endeksinde meydana gelebilecek bir birimlik şok petrol değişkeni üçüncü döneme kadar pozitif tepki verirken dördüncü dönemde negatif değerler almakta ve bu dönemden itibaren denge değerine doğru yaklaşmaktadır. Sanayi endeksinde meydana gelebilecek şok karşısında ise petrol değişkeni ikinci döneme kadar pozitif değerler almakta üçüncü dönemde negatif bir eğilim göstermekle birlikte bu dönemde itibaren denge değerinde olduğu görülmektedir.

Belçika; BEL20 endeksinden ham petrol değişkenine doğru tek yönlü bir nedensellik ilişkisi saptanmıştır Petrol meydana gelebilecek bir birimlik şok karşısında BEL20 ve BEL Sanayi 
endekslerinin tepkisinin anlamlı olmadı görülmektedir. BEL 20 ve BEL sanayi endekslerinde meydana gelebilecek bir birimlik şok karşısında petrol değişkenin zayıf formda pozitif tepki verdiği tespit edilmişti

Fransa; CAC Sanayi endeksinden ham petrol değişkenine doğru tek yönlü bir nedensellik ilişkisi saptanmıştır. Ham petrol fiyatlarında ki bir birimlik şok karşısında CAC Sanayi ve CAC Petrol\&Gaz endekslerinin tepkisinin anlamlı olmadığı görülürken iki endekste meydana gelebilecek bir şok karşısında petrol değişkenin pozitif tepki verdiği saptanmıştır.

Çalışmada, analize dahil edilen endeksler içerisinde sadece BIST100 endeksinden ham petrol değişkenine doğru bir ilişki saptanmıştır. Bu sonuçlar Özmerdivanlı (2014), Güler ve Nalın (2013)'ın çalışmalarıyla benzerlik göstermektedir. Etki-tepki analizi sonuçlarına göre petrol fiyatlarında meydana gelebilecek bir birimlik şok karşısında BIS100 etkisinin zayıf formda negatif BISTKIMPETROL\&PLASTIK ve BIST Sanayi endekslerinin ise zayıf formda pozitif yönde olduğu tespit edilmiştir.

Hindistan; BSE Sensex 30 endeksi ile ham petrol değişkeni arasında çift yönlü, Petrol\&Gaz endeksinden ham petrol değişkenine doğru tek yönlü bir nedensellik ilişkisi olduğu tespit edilmiştir. Bu sonuçlar Hindistan için hisse senedi ve petrol fiyatları arasında ilişki tespit eden Chittedi (2012) çalışmasıyla benzerlik göstermektedir. Ham petrol değişkeninde meydana gelebilecek bir birimlik şok karşısında BSE Sensex endeksinin tepkisinin dördüncü döneme kadar zayıf formda pozitif olduğu bu dönemden itibaren denge değerine doğru yaklaştığ görülmektedir. BSE Sensex endeksinde meydana gelebilecek bir şok ise petrol değişkeni ikinci döneme kadar pozitif tepki verirken beşinci döneme kadar negatif değerler aldığ görülmektedir. Petrol fiyatında meydana gelebilecek bir şoka Hindistan'ın Petrol\&Gaz endeksi üçüncü döneme kadar zayıf formda pozitif tepki verirken altıncı dönemden itibaren denge değerine yaklaştığı görülmektedir. Hindistan'ın Petrol\&Gaz endeksinde meydana gelebilecek bir şoka petrol değişkeni ikinci dönemden itibaren pozitif tepkiler vermekte ve beşinci dönem itibariyle denge değerine yaklaşmaktadır

Brezilya'da ise Bovespa endeksinden ham petrol değişkenine doğru tek yönlü bir nedensellik ilişkisi saptanmıştır. Ham petrol fiyatlarında meydana gelecek bir birimlik şok karşısında Bovespa endeksinin tepkisinin dördüncü döneme kadar pozitif olduğu bu dönemden itibaren denge değerine doğru yaklaştı̆̆ 1 görülmektedir. Bovespa endeksinde meydana gelebilecek bir birimlik şok karşısında ham petrol değişkeninin tepkisinin üçüncü döneme kadar pozitif olduğu dördüncü dönemde 0.007 lik negatif bir tepki vermekle birlikte bu dönemden itibaren sıfır denge değerine doğru yaklaştı̆̆ 1 tespit edilmiştir. Endonezya; FTSE Endonezya ve sanayi endeksinden ham petrol değişkenine doğru tek yönlü bir nedensellik ilişkisi olduğu tespit edilmiştir. Çalışmadan elde edilen sonuçlar G-20 ülkeleri için petrol fiyatları ile hisse senedi ve makroekonomik değişkenler arasında ilişki olduğunu tespit eden Pradhan vd. (2015) ve literatürde ki birçok çalışma ile benzerlik göstermektedir.

Çalışma önemli katkılara sahip olsa da ham petrol fiyatlarındaki değişimlerin borsa endekslerine etkisini sekiz ülke verileri ile gerçekleştirilmesi bir kısıttır. Gelecek çalışmalar için analiz döneminin genişletilmesi, kriz dönemlerinin de dahil edilerek karşılaştırma yapılması, petrol rezervi açısından güçlü olan ülkelerle gelişmiş ülkelerin analize dahil edilerek petrol fiyatlarındaki değişimlerin ülke grupları açısından karşılaştırmalı analizinin farklı yöntemler kullanılarak yapılması gelecek araştırmalar açısından faydalı olacağı düşünülmektedir. 


\section{Etik Beyan}

"Petrol Fiyatları İle Borsa Endeksleri Arasındaki Karşılıklı İlişkinin VAR Yöntemi İle Analizi: Türkiye Ve Seçilmiş Ülkeler" başlıklı çalışmanın yazım sürecinde bilimsel, etik ve alıntı kurallarına uyulmuş; toplanan veriler üzerinde herhangi bir tahrifat yapılmamış ve bu çalışma herhangi başka bir akademik yayın ortamına değerlendirme için gönderilmemiştir. $\mathrm{Bu}$ araştırmada hazır veri seti kullanıldığı için etik kurul kararı zorunluluğu taşımamaktadır.

\section{KAYNAKÇA}

Aktaş, M. ve Akdă̆, S. (2013). Türkiye'de Ekonomik Faktörlerin Hisse Senedi Fiyatları ile İlişkilerinin Araştırılması. International Journal Social Science Research, 2, 50-67.

Basher, S.A., Sadorsky, P. (2006). Oil Price Risk and Emerging Stock Markets, Global Finance Journal, Vol.17, s.224-251.

Basher, S. A. ve Sadorsky, P. (2016). Hedging Emerging Market Stock Prices with Oil, Gold, VIX, and Bonds: A Comparison Between DCC, ADCC and GO-GARCH, Energy Economics, 54, 235-247.

Chittedi, R.K. (2012). Do Oil Prices Matters for Indian Stock Markets? An Empirical Analysis, Journal of Applied Economics and Business Research, 2(1), 2-10.

Demirkale Ö. ve Ebghaei F. (2020). Ham Petrol Fiyatları İle Makroekonomik Ve Finansal Göstergeler Arasındaki Karşılıklı İlişkinin Var Modeli İle Analizi: Türkiye Üzerine Bir Uygulama. Finans Ekonomi ve Sosyal Araştırmalar Dergisi, 5(4), 688-698

El-Sharif I., Brown, D., Burton, B. Nixon B. ve Russell, A. (2005). Evidence on the Nature and Extent of the Relationship Between Oil Prices and Equity Values in the UK, Energy Economics, 27, 819-830.

Fuller, W.A., (1996) Introduction to Statistical Time Series, 2nd edition, John Wiley and Sons Inc.

Granger, C.W.J. (1969). Investigating Causal Relations by Econometric Models and Cross spectral Methods, Econometrica, 37(3), 424-438.

Güler, S., Tunc, R. ve Orcun, C. (2010), Petrol Fiyat Riski ve Hisse Senedi Fiyatları Arasındaki İlişkinin Belirlenmesi: Turkiye'de Enerji Sektoru Uzerinde Bir Uygulama, Ataturk Universitesi İktisadi ve İdari Bilimler Dergisi, 24(4), 297-315.

Gürlevik, F. ve Gazel, S. (2020). Enerji Fiyatlarındaki Değişimin Hisse Senedi Fiyatlarına Etkisi: Bist Elektrik Endeksi Üzerine Bir Uygulama. Ekev Akademi Dergisi, Y11: 24 Say1: 82 (Bahar 2020).

Güler, S., ve Nalın, H. T. (2013). Petrol Fiyatlarının İMKB Endeksleri Üzerindeki Etkisi. AİBÜİ̈B Ekonomik ve Sosyal Araştırmalar Dergisi, 79-97.

Güngör, B. ve Yerdelen, K. C. (2015). Dinamik Panel Veri Analizi İle Hisse Senedi Fiyatını Etkileyen Faktörlerin Belirlenmesi, KAÜ İ̈BF Dergisi, 6(9), 149-168.

Hammoudeh, S. ve Elesia, E. (2004), Dynamic Relationships among GCC Stock Markets and NYMEX Oil Futures, Contemporary Economic Policy, 22 (2), 250-269. 
Jones, C.M. ve Kaul, F. (1996). Oil and the Stock Markets. The Journal of Finance, 51(2) , 463491.

Kakacak, K., Meriç, E. ve Temizel, F. (2020). Petrol Fiyatlarının Bist100 Endeksi Üzerine Etkisinin Var Yöntemi İle Analizi. Business \& Management Studies: An International Journal, 8(5), 3751-3771.

Kiracı, K. (2020). Bist Ulaştırma Endeksi İle Dolar Endeksi Ve Petrol Fiyatları Arasındaki İlişkinin Ampirik Olarak Analizi. Finansal Araştırmalar ve Çalışmalar Dergisi, 12(22), ss. 180-189

Kök, D. ve Uyğur, M.E. (2014). Finansal Piyasalarda Fiyat Etkileşimi: BİST 100 ve Seçilmiş Finansal Göstergeler İçin VAR Analizi. Pamukkale Üniversitesi İşletme ve Bilişim Yönetimi Dergisi, 1(1), s.1-23

Maghyereh, A. (2004). Oil Price Shocks and Emerging Stock Markets: A Generalized VAR Approach. International Journal of Applied Econometrics and Quantitative Studies, 1-2, 2740.

Narayan, P. K. ve Narayan, S. (2009). Modelling The Impact of Oil Prices on Vietnam's Stock Prices, Applied energy, 87(1), 356-361.

Ono, S. (2011), Oil Price Shocks and Stock Markets in BRICs, The European Journal of Comparative Economics, 8(1), 29-45.

Öget, E. ve Şahin, S. (2017), Hisse Senetleri ile Altın Ons Fiyatları ve Ham Petrol Fiyatları Arasındaki Eşbütünleşme İlişkisi: Bist 100, Ulakbilge Sosyal Bilimler Dergisi, 5 (11), 637653.

Özmerdivanlı, A. (2014). Petrol Fiyatları ile BIST 100 Endeksi Kapanış Fiyatları Arasındaki İlişki. Akademik Bakış Dergisi, 43.

Park, J., Raitti, R. (2008). Oil Price Shocks and Stock Markets in The U.S and 13 European Countries. Energy Economics, Vol.30, Issue.5, 2587-2608.

Pradhan, R. P., Arvin, M. B., ve Ghoshray, A. (2015). The Dynamics of Economic Growth, Oil Prices, Stock Market Depth, and Other Macroeconomic Variables: Evidence from the G-20 Countries, International Review of Financial Analysis, 39, 84-95.

Regnier, Eva (2007), Oil And Energy Price Volatility, Energy Economics, 29 (3), pp. 405-427. doi: 10.1016/j.eneco.2005.11.003.

Sadorsky, P.(1999), Oil Price Shocks and Stock Market Activity, Energy Economics, 21(5), 449469.

Sims, C. A. (1980). Macroeconomics and Reality, Econometrica, 48(1), 1-48.

Syzdykova, A. (2018). Petrol Fiyatlarının BRIC Ülkelerinin Borsalarına Etkisi/The Impact Of Oil Prices On BRIC Countries' Stock Markets. Uluslararası Ekonomi İşletme ve Politika Dergisi, 2(1), 1-20.

Tüzemen, S. (2021). Petrol Fiyatlarının Türkiye'deki Hizmet Sektörü Hisse Senedi Fiyatları Üzerine Asimetrik Etkisinin Analizi. Atatürk Üniversitesi İktisadi ve İdari Bilimler Dergisi, Nisan 2021, 35(2). 